NBER WORKING PAPER SERIES

\title{
THE EFFECTS OF OFFERING HEALTH PLAN CHOICE WITHIN EMPLOYMENT-BASED PURCHASING GROUPS
}

\author{
M. Kate Bundorf \\ Working Paper 9996 \\ http://www.nber.org/papers/w9996 \\ NATIONAL BUREAU OF ECONOMIC RESEARCH \\ 1050 Massachusetts Avenue \\ Cambridge, MA 02138 \\ September 2003
}

This project was supported by funding from the Agency for Healthcare Research and Quality, Grant Number KO2 HS11668-01. The paper has benefited from comments from seminar participants at Stanford University, The National Bureau of Economic Research, and the 2003 Annual Meeting of the Academy of Health Services Researcher and Health Policy. The views expressed herein are those of the authors and are not necessarily those of the National Bureau of Economic Research.

C2003 by M. Kate Bundorf. All rights reserved. Short sections of text, not to exceed two paragraphs, may be quoted without explicit permission provided that full credit, including (C) notice, is given to the source. 
The Effects of Offering Health Plan Choice within Employment-Based Purchasing Groups M. Kate Bundorf

NBER Working Paper No. 9996

September 2003

JEL No. I1

\section{ABSTRACT}

Over the last two decades, employers have increasingly offered workers a choice of health plans. The availability of choice has the potentially beneficial effects of lowering the cost and increasing the quality of health care through greater competition among health plans for enrollees as well as allowing consumers to enroll in the type of coverage that most closely matches their preferences. On the other hand, concerns about the potential for adverse selection within employment-based purchasing in response to the availability of choice exist. In this paper, I examine the effects of offering choice in employment-based purchasing groups on access to and the cost of employersponsored coverage. I find that greater availability of choice was associated with a reduction in the premium of employer-sponsored coverage and an increase in the proportion of workers covered by the plans offered by employers. However, most of the premium reductions were due to a shift from family to single coverage within employment-based purchasing groups and a reduction in the generosity of the plans in which employees were enrolled. The results are not consistent with the availability of choice leading to lower premiums through greater competition among plans for workers.

M. Kate Bundorf

Department of Health Research and Policy

Stanford University School of Medicine

HRP Redwood Building, Room 257

Stanford, CA 94305-5405

and NBER

bundorf@stanford.edu 


\section{Introduction}

Over the last two decades, employers have increasingly offered workers a choice of health plans. From 1977 and 1998, the percent of employees offered more than one plan by their employer grew from $18 \%$ to $66 \%$ (Gabel 1999). Two explanations for the decision of employers to offer a choice among plans have been advanced in the literature. Employers offering a choice of plans may be implementing a managed competition approach to benefit design. Under managed competition, employers offer multiple plans with standardized benefits and require workers to pay the incremental premium for more expensive plans out-of-pocket. The objective is to create incentives for workers to make cost-effective enrollment decisions, which, in turn, encourages plans through greater competition for enrollees within a firm to increase the quality and lower the cost of the health care they provide (Enthoven and Kronick 1989).

The prevalence of health plan choice within employment-based purchasing groups, however, is not consistent with the widespread adoption of a managed competition approach to benefit design by employers. Long and Marquis (1998) examine the extent to which employers offer a choice of plans, require employees to pay the incremental premium associated with more expensive coverage, and provide quality information to employees and find that, in 1997, relatively few employers had adopted the managed competition model. Approximately $28 \%$ of employees offered a choice among plans faced an equal dollar employer contribution and only one-quarter of the largest employers offering a choice of plans provided employees with quality information. (Levy 1997) finds that only one-sixth of employee contributions to health plan premiums can be explained by the adoption of managed competition using employer survey data from 1993. 
An alternative explanation for the decision of employers to offer a choice among plans is that they are responding to heterogeneity among individuals within the firm in their preferences for health insurance (Goldstein and Pauly 1976). The hypothesis underlying this work is that employers minimize compensation costs by offering workers their optimal combination of cash wages and fringe benefits (Summers 1989). For employers hiring workers with varying preferences for health insurance, this implies that optimal compensation for the workforce requires offering multiple health plans, with each being the preferred choice of a subgroup of employees. Theoretical studies examining employer health benefit choices when employees vary in their preferences for coverage have demonstrated the tradeoffs employers may make between the costs of greater customization and their incentives to offer employees plans that more closely match individual preferences (Goldstein and Pauly 1976; Danzon 1989; Bundorf 2000). In these types of models, the existence of plan choice in employment-based purchasing groups is driven by heterogeneity in employee preferences for health insurance rather than a strategy to foster competition among plans.

Recent studies have provided some empirical evidence supporting the role of employee preferences in influencing employer health benefit choices. Variation in worker demographic characteristics is positively associated with the decision of employers to offer a choice of plans to workers and the extent of variation in the plans offered (Moran, Chernew et al. 2001; Bundorf 2002). Using tax prices as a measure of worker preferences, Gruber and Lettau (2000) find that both the median and the dispersion of tax prices within the firm explain the decision to offer coverage and the dollar value of coverage offered. Studies by Levy (1997) and Dranove, Spier et al. (2000) suggest that the use of employee premium contributions is driven by within-firm variation in health insurance preferences. While these studies suggest that workforce 
composition is a determinant of employer choices, they also do not explain a large proportion of employer purchasing behavior.

Relatively few studies have examined the implications of offering a choice of plans within employment-based purchasing groups, and those that do generally examine the managed competition approach to benefit design. In particular, Vistnes, Cooper et al. (2001) examine the assumption that competition among plans for enrollees within an employment-based purchasing group is necessary to generate gains from competition. In their theoretical work, they propose that competition among plans to be offered by an employer is equally or may be even more effective in lowering premiums. In their empirical work, however, they find support for managed competition in the sense that that premiums decline when employers offer additional plans and make a fixed dollar contribution to the plan premium.

Cutler and Reber (1998), however, provide evidence that requiring workers within a group to pay the full marginal cost of more expensive plans may lead to adverse selection within employment-based groups. They examine the effects of the switch to a managed competition style fixed premium contribution within a single employment-based purchasing group and find that gains from competition in the form of reduced premiums were offset by losses due to adverse selection. In the group they studied, the more generous PPO plan was eliminated by an adverse selection "death spiral" within 3 years of the introduction of the policy. The results suggest that offering plans that are differentially attractive to different risk types, in combination with a fixed employer premium contribution, will likely trigger significant adverse selection in insurance coverage ${ }^{1}$.

\footnotetext{
${ }^{1}$ A "pure" managed competition approach would require standardized benefits to reduce incentives for selection based on risk type.
} 
Taken together, these studies suggest that, while shifting the cost of more expensive plans to employees in the form of higher employer premium contributions may generate competitive pressures resulting in lower premiums, moving too aggressively in that direction may induce significant adverse selection within a group. Although it does not explicitly examine the effects of offering a choice of plans, one study questions even the competitive benefits of offering health plan choice (Feldman, Dowd et al. 1993). These authors find that offering an HMO raises the average premium per covered worker for both single and family coverage relative to offering only a fee-for-service plan. Not only were HMOs more costly than FFS plans, offering an HMO with a FFS plan increased the premium of the FFS plan, resulting in overall increases in the cost of employer-sponsored coverage. The study, however, was based on data from 239 Minnesota firms in 1986, suggesting that results are unlikely to be generalizable either to the nation as a whole or the current managed care environment. In addition, it is unlikely that the authors were able to adequately control for endogeneity in the decision to offer an HMO, potentially biasing the results.

While these studies provide important insight into the potential challenges facing employers in offering choice among plans, their results are somewhat at odds with overall trends in the market. While traditional FFS plans have been nearly eliminated from the market, PPOs, another less restrictive type of coverage, have co-existed and even thrived along with HMOs. Theoretical work suggests that multiple-choice arrangements with an employment-based group will not necessarily be plagued by adverse selection. Chernew and Frick (1999) demonstrate that the potential effects on equilibria of introducing a managed care type of product in the market are ambiguous. They model managed care as adding a third dimension, "managedness", to the premium and cost sharing product space and find that, in cases where an equilibrium existed in 
the two-dimension product space, the introduction of managed care may result in no equilibrium. On the other hand, managed care may generate an equilibrium in cases in which one did not exist in the two-dimensional analysis by allowing low-risk consumers an additional mechanism to distinguish themselves from high-risk consumers. In addition, employers may adopt premium contribution policies that support the stability of multiple-choice arrangement. Rather than adopting a fixed employer contribution, employers may set differential contributions across plans in order to maintain the stability of multiple choice arrangements in the face of risk variation among workers (Cutler and Reber 1998; Pauly and Herring 2000).

While numerous studies have demonstrated that existence of biased selection based health risk among different types of plans, with HMOs and managed care plans generally experience favorable selection (Hellinger 1995), this type of risk segmentation does not necessarily signal the existence of adverse selection (Pauly 1984). Preferences for health plans may be correlated with health risk, resulting in risk segmentation even in the absence of imperfect information. Based on this observation, Feldman and Dowd (2000) propose that managed care may be an efficient mechanism to segment risks, allowing low risk consumers to purchase full coverage at a price closer to the actuarially fair premium, although others have argued that the actions taken by plans to attract low risk consumers are inefficient (Newhouse 1996). Arguably, enrollment in HMOs in a firm offering a choice of plans may signal the existence of adverse selection if the workers enrolled in these types of plans would have preferred a more generous plans at the actuarially fair premium. However, studies examining enrollee satisfaction have found higher satisfaction among HMO enrollees with a choice among plans than those without a choice at the time of enrollment (Ullman, Hill et al. 1997; Gawande, 
Blendon et al. 1998). This is more consistent with efficient risk segmentation than the existence of widespread adverse selection.

In summary, relatively little is known about the effects on consumers of the trend toward greater prevalence of choice among health plans. The availability of choice has the potentially beneficial effects of lowering the cost and increasing the quality of health care through greater competition as well as allowing consumers to enroll in the type of coverage that most closely matches their preferences. On the other hand, concerns about the potential for adverse selection within employment-based purchasing in response to the availability of choice exist. In this paper, I examine the effects of offering choice in employment-based purchasing groups on access to and the cost of employer-sponsored coverage. I hypothesize that the introduction of managed care, HMOs specifically, facilitated the offering of choice within employment-based purchasing groups. I then use geographic variation in the availability of HMOs in the 1990 s as an instrument for offering health plan choice. I find that greater availability of choice was associated with reductions in the premiums of employer-sponsored coverage and increases in the proportion of workers covered by the plans offered by employers. However, most of the premium reductions were due to a shift from family to single coverage within employment-based purchasing groups and a reduction in the generosity of the plans in which employees were enrolled. The results are not consistent with the availability of choice leading to lower premiums through greater competition among plans for workers.

\section{Theoretical Framework}
A. The Employer's Decision to Offer a Choice of Plans 
The analysis is based on a model of an employer choosing a set of health benefits with the objective of minimizing total compensation costs when workers in a firm have heterogeneous preferences for health insurance. The model is based on two important assumptions. First, employees bear the full incidence of health insurance premiums in the form of lower cash wages. This is supported by empirical evidence of wage offsets based on average, but not individual, characteristics (Gruber 1994; Pauly and Herring 1999; Sheiner 1999). Second, variation exists among workers in their preferences for health insurance and imperfect sorting of workers among firms based on these preferences exist. This is also likely to be true. Individuals vary in income, risk aversion, and preferences for a style of care, all of which may affect their preferences for health insurance coverage. In addition, the matching of workers to jobs is likely to be influenced by factors other than health insurance preferences resulting in within firm variation in demand for health insurance.

In order to motivate the analysis of the effects of health plan choice, I present a simple theoretical model of the decision of an employer to offer a choice of plans. Assume a worker of type i maximizes utility, which is function of money $(\mathrm{m})$ and health insurance $(\mathrm{k})$, by allocating his or her total compensation between taxable cash wages (w) and health insurance. Let $\left(\begin{array}{c}* \\ w^{i}, k^{i}\end{array}\right)$ be the allocation between cash wages and health insurance that satisfies this condition for a worker of type i. In this analysis, this quantity is defined as the employee's benchmark quantity - the quantity the employee would have chosen in the absence of the employer as the purchaser. $^{2}$

\footnotetext{
${ }^{2}$ It is worthwhile to note that the employee's benchmark quantity is not the optimal quantity. By reducing the price of health insurance relative to cash wages, the tax treatment of health benefits creates incentives for workers to purchase greater amounts of health insurance than they would have otherwise. Thus, the tax treatment of employersponsored coverage creates welfare loss through the distortion of the quantity of coverage purchased by the
} 
For an individual employee, the employer's cost minimizing allocation of compensation between cash wages and health insurance is the employees' optimal allocation (Summers 1989). Thus, in a firm comprised of workers with homogeneous preferences for health insurance, an employer minimizing total compensation costs will offer a single plan, the most preferred plan of workers in the firm. More likely than the case of perfect sorting, however, is the existence of within firm heterogeneity in preferences for coverage. Goldstein and Pauly (1976) consider the case of a cost-minimizing firm choosing a single level of coverage to offer two types of workers. They assume the firm must hire a fixed quantity of workers of two different skill types due to production requirements and that preferences for health insurance are perfectly correlated within, but differ between, worker skill types.

The employer's problem is as follows:

$$
\underset{w^{A}, w^{B}, k}{\operatorname{Min}} C=L^{A}\left(w^{A}+\pi k\right)+L^{B}\left(w^{B}+\pi k\right)
$$

such that

$$
\begin{aligned}
& U^{A}\left[w^{A}\left(1-t^{A}\right), k\right] \geq \bar{U}^{A} \text { and } \\
& U^{B}\left[w^{B}\left(1-t^{B}\right), k\right] \geq \bar{U}^{B}
\end{aligned}
$$

where $\mathrm{L}^{\mathrm{i}}$ is the number of workers of type $\mathrm{i}$ and $\overline{U^{i}}=U^{i}\left({ }^{*} w^{i}, k^{*}\right)$. The reservation utility of a worker of type $\mathrm{i}$ is based on the assumption that the worker is able to obtain his or her benchmark wage and health insurance compensation package from an alternative employer. Solving the employer's problem produces the following condition defining the single level of coverage chosen by the firm.

employee. In addition, this excessive amount of coverage has second order effects on the quantity of health services consumed by employees due to the existence of moral hazard in health insurance (Pauly 1986). 


$$
L^{A}\left(\pi-\frac{U_{k}^{A}}{U_{m}^{A}\left(1-t^{A}\right)}\right)=-L^{B}\left(\pi-\frac{U_{k}^{B}}{U_{m}^{B}\left(1-t^{B}\right)}\right)
$$

In equation (2), the firm equates the cost of deviations from the optimal level of health insurance for each type of worker. The cost to the firm of increasing a unit of coverage is the per unit premium less the corresponding wage differential for each type of worker which is necessary to maintain the worker's reservation utility level. Assuming type A workers have stronger preferences for health insurance than type B workers, the single level of coverage chosen by the firm will be less than the benchmark level for these workers. Because the marginal utility of health insurance relative to wages for type A workers is greater than the marginal cost of health insurance, an increase in the level of coverage would result in a decrease in cash wages necessary to retain workers of type A that is greater than the price of the incremental unit of health insurance. For the type B workers, the firm offers a quantity of health insurance that is greater than the worker's benchmark quantity, and the value workers place on the incremental units is less than their marginal cost. Thus, increasing the amount of health insurance provided is costly to the firm in the sense that it would be less costly to compensate these workers in the form of additional cash wages.

Danzon (1989) quantifies the cost to the employer of heterogeneity in worker preferences when the firm offers only one plan:

$$
L^{B} \int_{* B}^{\hat{k}}\left[\pi k-\frac{U_{k}^{B}}{\left(1-t^{B}\right) U_{m}^{B}}\right] d k+L^{A} \int_{\hat{k}}^{*}\left[\frac{U_{k}^{A}}{\left(1-t^{A}\right) U_{m}^{A}}-\pi k\right] d k+F_{1}
$$

where $\hat{k}$ is the solution to the firm's one plan cost minimization problem, $\mathrm{t}^{\mathrm{i}}$ is the marginal tax rate for a worker of type $\mathrm{i}$, and $\mathrm{F}_{1}$ is the fixed cost of offering a single plan. The employer could 
reduce heterogeneity costs by offering workers of each type their benchmark wage and health insurance compensation package. However, offering multiple plans is also costly for the firm. These costs are in the form of increased loading resulting from fewer workers enrolled in each plan and the fixed costs of administering multiple plans. In deciding between offering one or two plans to a workforce made up of two types of workers, the firm's decision rule can be expressed as follows:

The firm offers two plans if:

$$
\frac{L^{B}}{L^{A}+L^{B}} \int_{k_{k}^{B}}^{\hat{k}}\left[\pi k(1-t)-\frac{U_{k}^{B}}{U_{w^{B}}^{B}}\right] d k+\frac{L^{A}}{L^{A}+L^{B}} \int_{\hat{k}}^{k_{k}^{A}}\left[\frac{U_{k}^{A}}{U_{w^{B}}^{A}}-\pi k(1-t)\right] d k>\frac{F_{2}-F_{1}}{L^{A}+L^{B}}
$$

where $F_{2}$ is the fixed cost of offering multiple plans.

Thus, the firm compares the cost, in the form of incremental wages, of not providing each type of worker with his or her benchmark level of coverage to the incremental cost of offering two plans. The decision to offer a choice of plans is a function of worker preferences for coverage, the number of workers overall and the number of workers of each type, the per unit price of health insurance.

In this model of employer behavior, employee premium contributions are necessary to induce workers to self-select into particular types of plans. The favorable tax treatment of employer-sponsored coverage is contingent upon satisfying certain non-discrimination requirements which are intended to prevent discrimination in the provision of fringe benefits in favor of highly compensated employees. While the specifics of the non-discrimination requirements vary by the funding and structure of the employer's health benefit plan, in general, they require that all plans offered by an employer are offered to all workers in the firm with some 
exceptions. ${ }^{3}$ based on age, full-time status, tenure with the firm, union status, and residency status. Thus, in a multiple-choice setting, employers may adopt employee contributions to create incentives for workers to enroll in less expensive plans. However, in many cases, employee premium contributions are not considered tax-exempt compensation. As a result, employers have incentives to minimize the size of these contributions. Bundorf (2000) finds that the differential tax treatment of employee and employer premium contributions, combined with the non-discrimination rule, creates incentives for employers to reduce the extent of differentiation between plans offered and reduces the extent to which offering multiple plans reduces total compensation costs when workers have heterogeneous preferences for coverage.

\section{B. The Effects of Offering a Choice of Plans}

In this model, employers make health benefit choices with the objective of minimizing total compensation costs for a given set of workers where total compensation costs are the sum of cash wages and health insurance premiums:

$$
T_{i}=\sum_{L} w_{l}+L^{c} * \bar{K}
$$

where $L$ represents the number of employees in the firm, $L^{c}$ is the number of workers covered by health insurance, $w_{l}$ is the cash wage received by employee 1 when the employer offers health insurance, and $\bar{K}$ is the average premium paid by the employer for health insurance. The employer offers a choice of plans if $T^{n>1}<T^{n=1}$ where $\mathrm{n}$ is the number of plans offered, and the primary empirical prediction is that offering a choice of plans will reduce total compensation costs.

\footnotetext{
${ }^{3}$ Exceptions include employees under the age of 25, part-time and seasonal workers, workers with less than 3 years of service, workers covered by a collective bargaining plan, and non-resident aliens.
} 
The effects on the components of total compensation, however, may vary. On net, the reduction in total compensation could be due to either a reduction in total cash wages, a reduction in total health insurance premiums, or a reduction in both. However, either component of compensation could increase if the corresponding reduction in the other were larger. For example, the average premium may increase for an employer offering a choice of plans rather than a single plan due to an increase in the generosity of coverage on average, if a more and less generous plan are offered, but a greater proportion of employees enroll in the more generous coverage. In addition, higher loading of premiums resulting from smaller numbers of workers enrolled in each plan could increase average premiums. Holding all else constant, however, differential selection of employees among plans should have no effect on average premiums. In the case that average premiums rise, the value that employees place on the new coverage must exceed the cost of providing it and employers must be able to make the corresponding wage adjustment. If premiums decrease on average, through a shift in enrollment to a lower cost plan, for example, in equilibrium, cash wages are likely to increase. However, the increase in cash wages would have to be less than the decrease in premiums to create incentives for employers to offer the new benefit. In either situation, the proportion of workers covered by the employer should be non-decreasing.

C. The effect of managed care on the decision to offer a choice among plans

Although the term "managed care" encompasses a wide range of health insurance products, in general, it refers to arrangements under which health insurers structure contracts with providers to influence the types of care plan enrollees receive (Glied 2000). In this analysis, the introduction and growth of managed care, and HMOs specifically, is considered an increase in the extent of product differentiation in the market. Consumers are likely to have differing 
preferences on the extent to which they value health insurance benefits in this managed form, and employers will offer a managed care plan if the product is more desirable for at least a subset of consumers within the firm or if it allows them to efficiently segment risks. Whether the availability of a new product increases the likelihood of an employer offering a choice of plans, however, depends on the extent to which consumers vary in the value they place on HMOs or managed care. If workers within a firm similarly place high value on the managed care plans, employers are likely to replace their existing coverage with the new product, rather than offering a choice of plans, and correspondingly, if workers within a firm similarly prefer non-managed care plans, the employer is unlikely to switch. However, if variation exists among workers within the firm in the value they place on this coverage or the employer is using the plan for efficient risk segmentation, the employer is likely to offer a choice of plans.

\section{Empirical Methods}

\section{A. Empirical Model}

Estimation is based on the following empirical model:

$$
\bar{T}_{i}=\alpha+\beta_{1} C_{i}+\beta_{2} X_{i}+\varepsilon_{i}
$$

where $\bar{T}_{i}$ represents total compensation per worker in firm i, assuming the number of workers in the firm is fixed, $\mathrm{C}_{\mathrm{i}}$ is an indicator of whether the employer offers workers a choice of plans $(n>1)$ and $X_{i}$ is a vector of variables which are controls for other exogenous determinants of firm level average workers compensation. This empirical framework can also be used to examine the individual components of total compensation:

$$
\begin{gathered}
\bar{W}_{i}=\alpha+\beta_{1} C_{i}+\beta_{2} X_{i}+\varepsilon_{i} \\
\bar{K}_{i}=\alpha+\beta_{1} C_{i}+\beta_{2} X_{i}+\varepsilon_{i} \\
P_{i}=\alpha+\beta_{1} C_{i}+\beta_{2} X_{i}+\varepsilon_{i}
\end{gathered}
$$


where $\bar{W}_{i}$ is average cash wage, $\bar{K}_{i}$ is the average premium, and $P_{i}=L^{c} / L$ is the proportion of workers covered by the employer. Because the effects of choice on cash wages and average premiums cannot be signed a priori based on the theoretical model, the effect of choice on these variables is an empirical question. However, the theoretical framework does predict that firms offering a choice of plans cover a greater or equal proportion of workers than if they offered a single plan.

A concern in estimating this model is that unobservable characteristics of firms may affect both the generosity of health insurance overall and the decision to offer a choice of plans. In addition, the decision to offer a choice of plans may be endogenous with respect to the dependent variables measuring total compensation. For example, firms with high average premiums under a traditional plan may be more likely to adopt a choice of plans than those with low average premiums. For these reasons, I use an instrument, an indicator of the availability of an HMO in the employer's county, to generate exogenous variation in the propensity of employers to offer a choice of plans to workers. The instrument is discussed in greater detail in section B.

A. Data

The primary data source is the 1993 Robert Wood Johnson Foundation (RWJF) Employer Health Insurance Survey (Long and Marquis 1997). The survey includes establishment level data for 22,890 public and private employers in ten states in 1993. The primary advantages of the survey for this analysis are that it was conducted at the establishment rather than the firm level, reducing the measurement error associated with a geographically based instrument, and during a time of rapid managed care penetration, which affects the validity of the instrument. Survey respondents provided information about the establishment and its workers 
and relatively detailed information about the health insurance plans offered. Cantor, Long et al. (1995) provide descriptive statistics and information on sampling methods and survey design. I exclude 1,516 public establishments and those reporting health insurance is negotiated by union contract because these types of establishments may follow an alternative model of decision-making. The study sample is also restricted establishments with greater than 25 employees and those that offer health insurance to workers. Establishment size is strongly correlated with both the probability of offering health insurance and the probability of offering a choice among plans (Figure 1). These differences suggest that the effect of the availability of HMOs on the decision to offer a choice of plans may differ based on establishment size. Preliminary testing using multivariate linear probability models revealed that the availability of an HMO in the county of the employer did not have a statistically significant effect on the probability of offering a choice of plans, conditional on offering health insurance, for establishments with 25 or fewer workers. However, the availability of HMOs did have a positive effect on the probability of offering health insurance for these smaller employers, particularly for those with 10 or less employees. These results suggest that the decision to offer a choice of plans, and particularly the role of HMO availability in facilitating choice, is most relevant for employers with greater than 25 workers. I eliminate 7,118 establishments not offering health insurance and 9,589 establishments with 25 or less employees. Of the remaining 4,667 establishments I exclude 118 for missing or invalid data for key study variables, primarily industry and state identifiers. 4,549 observations remain in the study sample.

\section{Dependent Variables}

The focus of the empirical work is the health benefits offered by employers, including health insurance premiums and coverage rates. Although cash wage compensation is an 
important component of the theoretical analysis, the establishment level survey does provide adequate and reliable data to test hypotheses regarding cash wage compensation ${ }^{4}$. As a result, measures of total and cash wage compensation are not analyzed in this paper. Each dependent variable is described below.

Three dependent variables measure premium per covered worker in the establishment and the allocation of average spending between employer and employee premium contributions:

1. Average premium: the average premium for plans provided by the employer, weighted by the proportion of workers enrolled in each plan and the distribution of enrolled workers between single and family coverage.

2. Average employer contribution: the average employer contribution to the premium for plans provided by the employer, weighted by the proportion of workers enrolled in each plan and the distribution of enrolled workers between single and family coverage.

3. Average employee contribution: the average employee contribution to the premium for plans provided by the employer, weighted by the proportion of workers enrolled in each plan and the distribution of enrolled workers between single and family coverage.

The variables above include information on both the generosity of the plans offered by the employer based on plan characteristics as well as employee coverage decisions regarding dependents. In order to isolate plan from coverage generosity, I estimate models using two measures of plan generosity. The first measures employer spending on premiums independent of employee coverage decisions. The second controls for potential differences across plans in

\footnotetext{
${ }^{4}$ The survey does provide information on the distribution of worker wages based on four broad categories. However, in establishments offering health insurance, over $40 \%$ of workers fall into the highest wage category, making it unlikely that this variable will allow me to capture small effects on the wage distribution. Another candidate variable is total annual payroll combined with total annual labor hours. However, the median value of payroll per hour for establishments in the sample is over $\$ 200$, raising questions regarding the validity of the reported values.
} 
characteristics that affect the generosity of coverage. The objective of this variable is to isolate competitive effects on premiums from potential changes in plan generosity related to offering a choice of plans.

4. Average single premium: the average premium for plans provided by the employer assuming all workers are enrolled in single coverage of each plan, weighted by the proportion of workers enrolled in each plan.

5. Average standardized premium: the average of the premium for single coverage, holding plan generosity constant, weighted by the proportion of workers enrolled in each plan. Premiums are standardized using a regression model of the relationship between plan characteristics and employer characteristics and plan premiums for single coverage. The model is estimated on plan level data including 19,031 plans offered by employers included in the RWJF survey using ordinary least squares. A standardized premium was calculated for each plan by predicting the premium holding the plan characteristics constant at the mean in the sample. The average standardized premium is the average of these predicted values for each employer. Appendix Tables 1 and 2 present descriptive statistics and the results of the estimation.

A key hypothesis from the theoretical model is that offering a choice of plans increases the proportion of workers in a firm covered by the health insurance offered by the employer. The following dependent variables test this and also directly examine shifts between single and family coverage:

6. Proportion covered: the proportion of employees covered by the plans offered by the employer. 
7. Proportion family coverage: the proportion of covered employees enrolled in family coverage.

Finally, I examine variables describing employer contribution policies to identify a mechanism for observed coverage changes:

8. Full contribution -single coverage: Indicator of whether the employer contributes the full premium for single coverage for at least one plan.

9. Full contribution-family coverage: Indicator of whether the employer contributes the full premium for family coverage for at least one plan.

Summary statistics for dependent variables are presented in table 1 . $\underline{\text { Independent Variables }}$

The study variable of primary interest is the indicator of whether the establishment offers a choice among health plans. The models also include a set of exogenous firm and market characteristics to control for other factors that contribute to differences across establishments in employee compensation. Establishment controls include establishment size (categorical indicators $1-10,11-25,26-50,51-100,101-250$, and $>250$ employees), whether the establishment is part of a larger nationwide organization (to control for economies of scale in the purchase of health insurance and employee compensation), for-profit status, and the distribution of the workforce by age and sex. The survey collects information on the proportion of workers falling into three age categories: $<25$ years, $25-54$ years, and 55 and older by sex. Using these variables, I also construct a measure of heterogeneity in preferences for coverage among workers in the firm based on their predicted health expenditures, an estimate of the coefficient of variation of predicted health expenditures (Bundorf 2000). In some models, I include the wage distribution of workers in the firm to control for differences in demand for coverage across 
establishments. Because these variables are likely to be endogenous, however, I exclude them from most specifications. Market controls include the county population, the county per capita income, the HCFA wage index and characteristics of the medical market including percent of county discharges that were financed by Medicaid and the number of inpatient-hospitals in the county offering residency programs. All models also include state (10) and industry (9) fixed effects. Descriptive Statistics are presented in Table 2.

$\underline{\text { Instrumental Variables }}$

As discussed earlier, the effect of choice in the empirical model is likely to be biased by differences in unobserved characteristics between establishments offering and those not offering a choice of plans as well as the endogeneity of choice with respect to premiums. I address these issues by instrumenting for the propensity of employers to offer a choice of plans with an indicator of whether an HMO is available in the county of the establishment. I hypothesize that the availability of an HMO creates an alternative coverage choice, which allows employers to more effectively segment workers based on preferences for health care and health insurance than variations in cost sharing in a traditional indemnity plan. The identifying assumptions are that the availability of managed care lowers the cost to the employer of offering a choice among plans and that the entry of managed care organizations into a market is independent of the characteristics of the employers in that market. One potential weakness of this strategy is that demand for HMOs differs across counties and the availability of managed care plans represents differences in the average demand across firms in the county rather than random variation in HMO location choices. The year of the data used in the analysis addresses this issue somewhat. Managed care penetration was increasing rapidly during this period. In $1991,60 \%$ of countries had at least one HMO serving the country (Table 3). By 1996, this had grown to 93\%. I propose 
that the rapid entry during these years was conducted independent of employee demand for health insurance within individual firms. Managed care organizations were not able to accurately assess systematic differences across markets in employee preferences for coverage and instead made decisions based on factors such as market size and the existing organization of providers. In line with this hypothesis, I estimate an additional set of models restricting my analysis to markets in which an HMO had entered by 1996, suggesting that the market was ultimately attractive to HMOs.

C. Model estimation

All models are estimated using either ordinary least squares or two stage least squares. The first stage models are linear probability models, which will produce consistent estimates using two stage least squares (Heckman 1978). Heteroskedasticity consistent standard errors are calculated for all models presented (White 1980).

\section{Results}

Thirty-seven percent of establishments in the study sample offered a choice of plans (Table 1). Average health insurance premiums were higher in firms offering a choice of plans (\$257) than those offering a single plan (\$244). Employers offering a choice of plans, however, also made larger contributions to the plan premium (\$177) than those offering a single plan (\$163), with the result that average employee contributions were similar between the two types of firms. The average monthly premium assuming all employees were enrolled in single coverage of their chosen plan was also similar between the two types of firms (\$143). Holding plan generosity constant, however, plan premiums were higher for firms offering a choice of plans were higher in establishments offering plan choice $(\$ 143)$ than those offering a single plan 
(\$140). This is consistent with the proposition that firms choosing to offer a choice of plans were those facing higher average premiums due to factors such as the composition of the workforce or local health care costs. Both the proportion of employees covered (0.71 vs 0.60$)$ and the proportion of enrollees with family coverage ( 0.47 vs 0.45$)$ were higher in establishments offering a choice of plans. Establishments offering a choice of plans were also more likely to fully contribute to at least one plan in the case of both single and family coverage.

These results are consistent with employers offering a choice of plans offering more generous benefits in general. Employers offering a choice of plans cover a higher proportion of employees and provide family coverage to a greater proportion of covered workers. In addition, they are more likely to offer a plan requiring no employee contribution to the plan premium. Although average premiums for single coverage are similar between employers offering a choice of plans and those offering a single plan, adjusting for plan generosity indicates that underlying premiums are actually higher for employers offering a choice. This indicates that the plans in which workers enroll in these establishments are actually less generous based on their observable plan characteristics.

In the first stage regression, the indicator of whether an HMO is available in the establishment's county has a large, positive and statistically significant effect on the probability of offering a choice among plans (Table 4). The availability of an HMO in the country of the establishment increases the likelihood that the employer offers a choice of plans by 14 percentage points in the full sample (Table 4-Models 1 and 2) and 15 percentage points in the subsample based on the future availability of an HMO in the establishment's county (Table 4Models 3 and 4). Including the wage distribution of workers in the firm as controls for variation across establishments in demand for health insurance has virtually no effect on the magnitude or 
statistical significance of the effect of HMO availability, reducing concerns of omitted variables measuring worker demand for coverage. As anticipated, establishment size is highly correlated with the probability of offering a choice of plans. Establishments with more employees and establishments that are part of a larger firm are more likely to offer a choice among plans. Variation in workers preferences for coverage as proxied by variation in expected health expenditures is also positively correlated with the decision to offer a choice of plans as expected.

The results of the models for average premium indicate that offering a choice of plans reduced the average premium paid by employers for workers and that the primary mechanism for the reduction was an associated shift from family to single coverage. The point estimates of the effect of offering a choice of plans using OLS are small and not statistically significant (Table 5, Models 1-3). The effect of choice on average premium in the instrumented model, however, is large, negative and statistically significant (Table 5, Models 4 and 6). In these models, offering a choice of plans reduces the average premium for employer-sponsored coverage by $\$ 85$ to $\$ 100$. Although this seems implausibly large at first glance, the results from Models 5 and 6 suggest that most of the effect was driven by a shift from family to single coverage. Controlling for the proportion of employees enrolled in family coverage, the magnitude of the effect of choice declines substantially and becomes statistically insignificant at conventional levels. In Models 5 and 6, the proportion of workers enrolled in an HMO does not have a statistically significant effect on the average premium within an employer-sponsored group.

Tables 6 and 7 examine the allocation of these premium reductions between employee and employer premium contributions. OLS results reveal a small, statistically insignificant positive effect of choice on both employee and employer premium contributions. IV estimates, in contrast, reveal larger negative effects on both employer and employee contributions. 
However, the negative effect is only statistically significant in the model of the employer contribution using the full sample (Table 6 - Model 4). In the instrumented models, controlling for the proportion enrolled in family coverage generally reduces the magnitude of the point estimate of the effect of choice on both employee and employer premium contributions, although the effect is larger for employer contributions (Tables 6 and 7 - Models 5 and 6). Comparing the magnitude of the decline in contributions in the employee and employer premium contribution models with those of the average premium model, I find that between 65 and $75 \%$ of the decline in premiums was in the form of declining employer contributions. The remainder was passed on to employees directly in the form of lower premium contributions. Offering a choice of plans does not have a statistically significant effect on the average employer share of the premium for covered workers (Table 8). In the instrumented models, the point estimates are positive (Table 8 - Models 4 and 6), indicating that employers contributed a higher proportion of the plan premium in firms offering a choice of plans, although once again, these effects are not statistically significant.

I control for the effects of changes in premiums driven by changes in coverage by calculating average premiums assuming single coverage for all employees enrolled in a plan. Using OLS, I find the offering a choice of plans was associated with a small reduction in average premiums, about $\$ 5$ (Table 8 - Models 1 and 2). Much of the reduction can be explained by a shift to HMO enrollment (Model 3). The magnitude of the negative effect is larger, however, using instrumental variables. In the full sample, offering choice reduces the average premium for single coverage by $\$ 41$, and controlling for the proportion enrolled in an HMO has little effect on the estimate. Although these seems implausibly large given the average in the data for the average premium assuming single coverage is $\$ 143$, it is important to consider that these 
estimates do not control for differences in the generosity of the plans offered. For example, employers adding an HMO to a more traditional FFS plan may increase the cost sharing of the FFS plan to induce employees to enroll in the HMO. These types of changes would presumably be reflected as changes in the premium for the affected plan.

The results in Table 10 suggest that these types of changes in the generosity of plans may take place when firms offer a choice of plans to workers. The dependent variable in these models is the average premium, holding plan generosity constant, for covered employees assuming all employees are enrolled in single coverage of a particular plan. In this case, I find that offering a choice of plans has virtually no effect on average standardized premiums. The point estimates are small relative to the mean of the dependent variable (\$141) and generally statistically insignificant. These results suggest that the negative effects of average premiums for single coverage were largely driven by corresponding changes in plan generosity. Similarly, they provide no evidence that offering a choice of plans drives reductions in plan premiums through competitive effects.

The results suggest that offering a choice of plans increases the proportion of workers in a firm covered by health insurance (Table 11). Using OLS, offering a choice of plans is associated with an increase of 5 percentage points in the proportion of workers in the establishment covered by health insurance (Table 11 - Models 1 and 2). This is true even after controlling for the wage distribution of workers. Using IV, the estimates are of similar magnitude and direction, unlike the results for the other dimensions of employer health benefit offerings. However, the estimates are less precisely estimated and are not statistically significant (Table 11 - Models 3 and 4). 
Although offering choice is associated with an increase in the proportion of employees within an establishment covered by health insurance, IV estimates suggest that it is also associated with a significant shift from single to family coverage among covered workers (Table 12). Using OLS, offering a choice is associated with a 2 percentage point increase in the proportion of covered workers enrolled in family coverage (Table 12 - Models 1 and 2). However, IV estimates suggest significant, approximately 20 percentage point, declines in the proportion of workers enrolled in family coverage. The results in Table 13 indicate a possible mechanism for the dramatic declines. The dependent variables in this analysis are whether the employer contributes fully to at least one single coverage plan and at least one family coverage plan. Using OLS, employers offering a choice of plans were 8 percentage points more likely to fully contribute to at least one single coverage plan (Table 13- Model 1) and 4 percentage points more likely to fully contribute to a family coverage plan (Table 13-Model 4). However, using instrumental variables, the magnitude of the effect of choice on the probability of offering the full contribution single plan was much higher - over 20 percentage points, while the effect of offering a choice of plans on the probability of fully contributing to a plan providing family coverage was negative - between 2 and 6 percentage points. The IV estimates, however, are imprecisely estimated and thus can only be considered suggestive.

\section{Conclusions}

The prevalence of health plan choice within employment-based purchasing groups has increased over the last two decades. This results of this analysis of the effects of offering a choice among plans within employment-based purchasing groups are more consistent with a model of employers choosing to offer a choice of plans in response to heterogeneity among 
workers in their preferences for health insurance than with the objective of generating competition to reduce the premiums and increase the quality of the health plans they provide. I find that the availability of health plan choice was associated with an increase in the proportion of workers in a firm covered by the health insurance offered by the employer and reduction in average premiums for employer-sponsored coverage. Premium reductions, however, took place primarily through reductions in the generosity of coverage received by employees, both in the form of less generous plans and fewer workers within a firm enrolling in family coverage. I find no evidence that the availability of choice among plans generated premium reductions through greater competition among health plans for enrollees within the firm.

The analysis also indicates the importance of generating exogenous variation in determinants of employer choices, in this case the decision to offer a multiple plans, to examine the effects of these choices on workers. In this analysis, I use the availability of an HMO in the county of the employer as an instrument for offering a choice of plans. While the results for the effects of choice on the proportion of workers covered by the employer were consistent between the OLS and IV models, many of the other results were not. In particular, the findings regarding reductions in both plan and coverage generosity associated with health plan choice were specific to the IV estimation. The opposite conclusions would have been drawn using OLS. This could potentially be driven by both unobserved characteristics of workers or firms positively affecting both the generosity of the benefits offered by the employer and compensation more generally and the decision of the employer to offer choice or the endogeneity of the decision to offer a choice of plans with respect to employer spending on health insurance. Employers characterized by higher average premiums for reasons independent of the generosity of the plans they offered may 
have been more likely to offer a choice of plans in response. Either case would result in a positive relationship between choice and premiums using OLS.

Overall, the findings indicate that gains in employee coverage were offset by both declines in the generosity of plans offered by employers and losses in dependent coverage. The implications for the welfare of consumers are dependent upon the extent to which consumers valued the lost benefits as well as the extent to which they were compensated for their loss. For example, reductions in plan generosity, such as the switch from a FFS plan to an HMO or an increase in cost sharing, may represent either a reduction in highly valued benefits or a movement away from inefficiently high levels of coverage. Workers gaining coverage are likely to be better off, particularly if they were previously uninsured. In the case of declines in dependent coverage, the welfare implications depend on the extent to which dependents had access to coverage from alternative sources. If these declines primarily targeted dual-working families who were enrolled in potentially duplicative plans, this may have had positive welfare implications. If those who lost dependent coverage were able to find it from an alternative employer or public source, the changes represent a transfer rather than an inefficiency. However, for those who lost coverage and went uninsured, the change was ultimately welfare reducing.

For reductions in both plan and coverage generosity, the net effect for individual workers also depends upon whether they coincided for corresponding increases in cash wages or other fringe benefits. While one mechanism for transferring compensation to workers is by reducing employee premium contributions, the results do not indicate that employers passed the bulk of the premium on to employees in the form of higher employer contributions to plan premiums. 
However, we were unable to directly examine the effects of changes in benefits on cash wages, either at the level of the establishment or the level of the individual.

In addition, it is important to note that the changes observed in the instrumented models, particularly in the case of the declines in family coverage, may not have been a direct result of offering health plan choice, but rather driven by underlying changes in the health care market that coincided with or even drove the diffusion of managed care. For example, rising health care costs may have created pressure for employers to reduce health benefit costs. This may have been accomplished by two strategies, a shift to managed care and a reduction in contributions to dependents.

The findings of this study make three important contributions to the literature on health plan choice. First, they provide greater support for the decision of employers to offer a choice of health plans as a response to heterogeneity among employees in their preferences for health insurance than an explicit strategy to foster within-firm competition among plans for enrollees. Similarly, the results are not consistent with widespread adverse selection in response to employers offering workers a choice among plans. The availability of choice was associated with an increase, rather than a decline, in the proportion of workers in an establishment covered by the health insurance offered by the employer. Although the availability of choice appears not to be driving declines in within firm coverage rates due to adverse selection, it is possible that choice is welfare reducing for some workers if, for example, they are enrolled in a managed care plan when they would prefer an alternative type of plan. This, however, is not consistent with literature indicating that those enrolled in HMOs who faced a choice of plans are more satisfied with their coverage than those not facing a choice. Finally, the results highlight the importance of considering household decision making when evaluating the effects of employer decisions. 
Our results indicate that many employees responded to the availability of choice from an employer by dropping coverage for dependents. Yet, evaluating the implications of this requires more information on the coverage alternatives available to dependents and their ultimate choices. 


\section{References:}

Bundorf, M. K. (2000). Employee Demand for Health Insurance and Employer Health Benefit Choices. Philadelphia, PA, University of Pennsylvania: 1-143.

Bundorf, M. K. (2002). "Employee Demand for Health Insurance and Employer Health Plan Choices." Journal of Health Economics 21: 65-88.

Cantor, J. C., S. H. Long, et al. (1995). "Private Employment-based Health Insurance in Ten States." Health Affairs 14(2): 199-211.

Chernew, M. E. and K. D. Frick (1999). "The impact of managed care on the existence of equilibrium in health insurance markets." Journal of Health Economics 18: 573-592.

Cutler, D. M. and S. Reber (1998). "Paying for Health Insurance: The Tradeoff between Competition and Adverse Selection." Quarterly Journal of Economics 113(2): 433-466.

Danzon, P. M. (1989). Mandated Employment-based Health Insurance: Incidence and Efficiency Effects.

Dranove, D., K. Spier, et al. (2000). "Competition Among Employers Offering Health Insurance." Journal of Health Economics 19(1): 121-.

Enthoven, A. and R. Kronick (1989). "A Consumer-Choice Health Plan for the 1990s: Universal Health Insurance in a System Designed to Promote Quality and Economy." The New England Journal of Medicine 320(1): 29-37.

Feldman, R. and B. Dowd (2000). "Risk segmentation: goal or problem?" Journal of Health Economics 19: 499-512.

Feldman, R., B. Dowd, et al. (1993). "The Effect of HMOs on Premiums in Employment-Based Health Plans." Health Services Research 27(6): 779-811.

Gabel, J. R. (1999). "Job-Based Health Insurance, 1977-1998: The Accidental System Under Scrutiny." Health Affairs 18(6): 62-74.

Gawande, A. A., R. J. Blendon, et al. (1998). "Does Dissatisfaction with Health Plans Stem from Having No Choices?" Health Affairs 17(5): 184-194.

Glied, S. (2000). Managed Care. Handbook of Health Economics. A. J. Culyer and J. P. Newhouse. New York, Elsevier Science B. V. 1A: 708-53.

Goldstein, G. S. and M. V. Pauly (1976). Group Health Insurance as a Local Public Good. The Role of Health Insurance in the Health Services Sector. R. N. Rosett. New York, National Bureau of Economic Research: 73-110.

Gruber, J. (1994). "The Incidence of Mandated Maternity Benefits." American Economic Review 84(3): 622-641.

Gruber, J. and M. Lettau (2000). How Elastic is the Firms's Demand for Health Insurance?, National Bureau of Economic Research.

Heckman, J. J. (1978). "Dummy Endogenous Variables in a Simultaneous Equation System." Econometrica 46(4): 931-959.

Hellinger, F. J. (1995). "Selection Bias in HMOs and PPOs: A Review of the Evidence." Inquiry 32(Summer (2)): 135-42.

Levy, H. (1997). Who Pays for Health Insurance? Employee Contributions to Health Insurance Premiums. Working Paper.

Long, S. H. and M. S. Marquis (1997). Robert Wood Johnson Foundation Employer Health Insurance Survey, 1993 [Computer File\}. Ann Arbor, MI, ICPSR.

Long, S. H. and M. S. Marquis (1998). How Widespread is Managed Competition? Data Bulletin. Washington DC, Center for Studying Health System Change. 
Moran, J. R., M. E. Chernew, et al. (2001). "Preference Diversity and the Breadth of Employee Health Insurance Options." Health Services Research 36(5): 911-934.

Newhouse, J. P. (1996). "Reimbursing Health Plans and Health Providers: Efficiency in Production Versus Selection." Journal of Economic Literature XXXIV(September): 1236-1263.

Pauly, M. V. (1984). "Is Cream-Skimming a Problem for the Competitive Medical Market?" Journal of Health Economics 3: 87-95.

Pauly, M. V. and B. Herring (1999). Pooling Health Insurance Risks. Washington DC, AEI Press.

Pauly, M. V. and B. Herring (2000). "An efficient employer strategy for dealing with adverse selection in multiple-plan offerings: an MSA example." Journal of Health Economics 19(4): 513-528.

Sheiner, L. (1999). Health Care Costs, Wages, and Aging. Washington D.C., Federal Reserve Board of Governors.

Summers, L. H. (1989). "Some Simple Economics of Mandated Benefits." American Economic Review 79(2): 177-183.

Ullman, R., J. W. Hill, et al. (1997). "Satisfaction and Choice: A View from the Plans." Health Affairs 16(3): 209-217.

Vistnes, J. P., P. F. Cooper, et al. (2001). "Employer Contribution Methods and Health Insurance Premiums: Does Managed Competition Work?" International Journal of Health Care Finance and Economics 1: 159-187.

White, H. (1980). "A heteroscedasticity-consistent covariance matrix estimator and a direct test for heteroskedasticity." Econometrica 48: 817-838. 
Figure 1: Employer Health Plan Offerings by Establishment Size

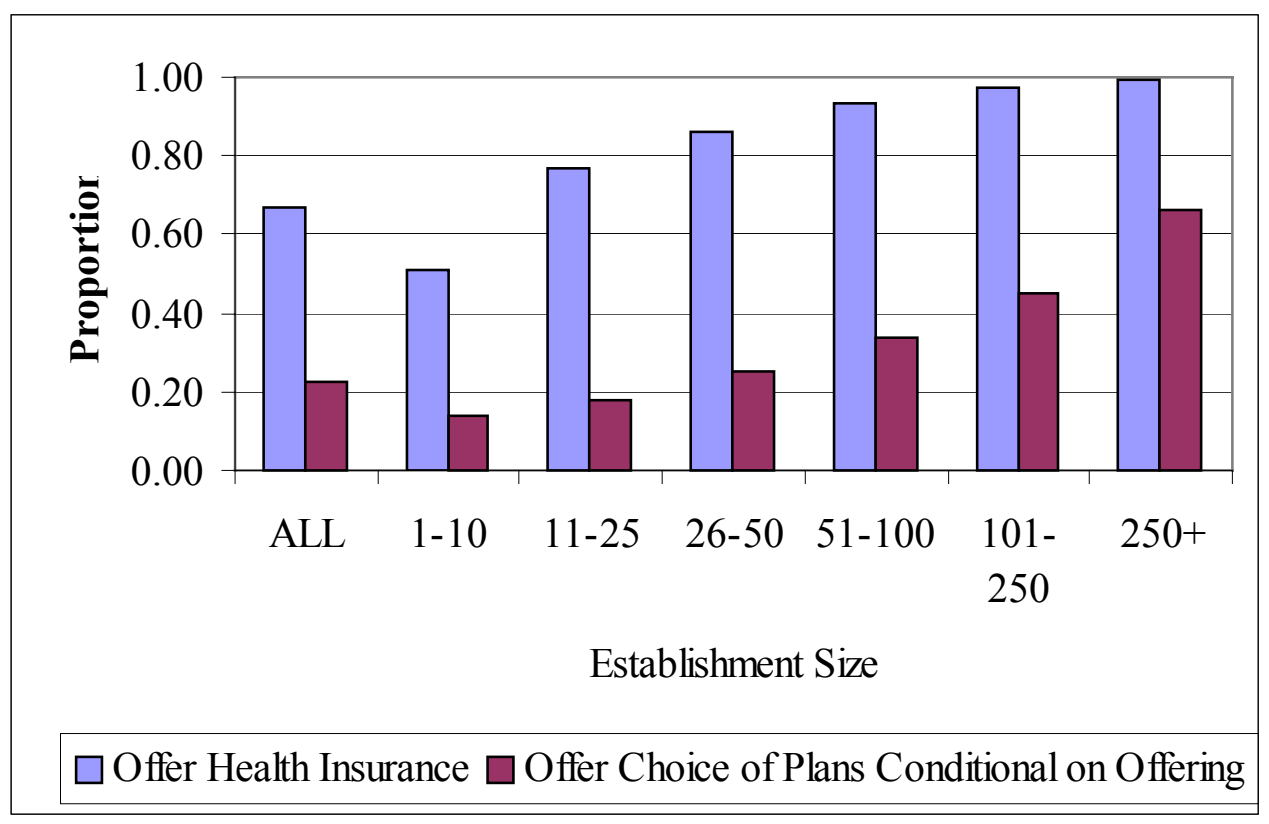

Note: Based on author's calculation from data from the 1993 Robert Wood Johnson Foundation Employer Health Insurance Survey. Public employers and establishments in which health insurance is union negotiated are excluded from the sample. 
Table 1: Dependent Variables by Offer of Choice

\begin{tabular}{|c|c|c|c|c|c|c|}
\hline & \multicolumn{2}{|c|}{ All } & \multicolumn{2}{|c|}{ No Choice } & \multicolumn{2}{|c|}{ Choice } \\
\hline & Mean & S.D. & Mean & S.D. & Mean & S.D. \\
\hline Average Premium & 248.74 & 104.18 & 243.82 & 110.17 & 257.09 & 92.56 \\
\hline Average Employer Contribution & 168.51 & 99.91 & 163.30 & 104.02 & 177.36 & 91.87 \\
\hline Average Employee Contribution & 80.23 & 71.20 & 80.52 & 76.57 & 79.73 & 61.02 \\
\hline Average Employer Share & 0.67 & 0.24 & 0.66 & 0.25 & 0.68 & 0.21 \\
\hline Average Premium-Single Coverage & 143.07 & 54.75 & 143.46 & 60.01 & 142.40 & 44.43 \\
\hline Average Premium - Standardized & 141.48 & 15.44 & 140.37 & 15.45 & 143.36 & 15.25 \\
\hline Proportion Covered & 0.64 & 0.30 & 0.60 & 0.31 & 0.71 & 0.27 \\
\hline Proportion Family Coverage & 0.46 & 0.25 & 0.45 & 0.27 & 0.47 & 0.22 \\
\hline Full Contribution Single Coverage & 0.41 & 0.49 & 0.38 & 0.49 & 0.46 & 0.50 \\
\hline Full Contribution Family Coverage & 0.15 & 0.36 & 0.13 & 0.34 & 0.18 & 0.39 \\
\hline $\mathrm{N}$ & \multirow{2}{*}{\multicolumn{2}{|c|}{4549}} & \multicolumn{2}{|c|}{2863} & \multicolumn{2}{|c|}{1686} \\
\hline$\%$ & & & \multicolumn{2}{|c|}{0.63} & \multicolumn{2}{|c|}{0.37} \\
\hline
\end{tabular}

* significant at $10 \% ; * *$ significant at $5 \% ; * * *$ significant at $1 \%$ 
Table 2: Independent Variables

\begin{tabular}{|c|c|c|}
\hline \multirow[b]{2}{*}{ Variable } & \multicolumn{2}{|c|}{$\mathrm{n}=4,549$} \\
\hline & Mean & Std. Dev \\
\hline Offers a Choice of Plans & 0.37 & 0.48 \\
\hline Proportion Enrolled in Family Coverage & 0.46 & 0.25 \\
\hline Proportion Enrolled in HMO & 0.20 & 0.35 \\
\hline 26-50 employees & 0.40 & 0.49 \\
\hline 51-100 employees & 0.26 & 0.44 \\
\hline 101-250 employees & 0.21 & 0.41 \\
\hline $250+$ employees & 0.12 & 0.33 \\
\hline Part of a larger firm & 0.55 & 0.50 \\
\hline For Profit & 0.84 & 0.37 \\
\hline$\%$ Wage $<\$ 10,000$ & 11.87 & 22.64 \\
\hline$\%$ Wage $\$ 10-14,000$ & 22.55 & 24.27 \\
\hline$\%$ Wage $\$ 14-20,000$ & 23.39 & 21.42 \\
\hline$\%$ Wage $>\$ 20,000$ & 42.23 & 33.95 \\
\hline Health Expenditure Variation & 0.37 & 0.10 \\
\hline$\%$ Male $<25$ years & 0.12 & 0.15 \\
\hline$\%$ Male $25-54$ & 0.37 & 0.25 \\
\hline$\%$ Male $>=55$ & 0.04 & 0.06 \\
\hline$\%$ Female $<25$ years & 0.11 & 0.13 \\
\hline$\%$ Female $25-54$ & 0.32 & 0.23 \\
\hline$\%$ Female $>=55$ & 0.04 & 0.06 \\
\hline County Population 10,000 s & 46.89 & 51.23 \\
\hline County Per Capita Income $1,000 \mathrm{~s}$ & 21.42 & 6.90 \\
\hline County per capita Medicaid discharges & 18.28 & 11.96 \\
\hline Teaching Hospitals & 2.90 & 3.65 \\
\hline HMO Available in County-93 & 0.88 & 0.33 \\
\hline CMS wage index & 96.49 & 15.42 \\
\hline Agriculture/Forestry \& Fisheries & 0.01 & 0.11 \\
\hline Construction & 0.03 & 0.18 \\
\hline Mining and Manufacturing & 0.20 & 0.40 \\
\hline Transportation/Communications/Other Public Utilities & 0.06 & 0.23 \\
\hline Wholesale Trade & 0.07 & 0.25 \\
\hline Retail Trade & 0.20 & 0.40 \\
\hline Finance/Insurance/Real Estate & 0.14 & 0.35 \\
\hline Professional Services & 0.24 & 0.42 \\
\hline Other Services & 0.05 & 0.22 \\
\hline Colorado & 0.10 & 0.30 \\
\hline Florida & 0.10 & 0.30 \\
\hline Minnesota & 0.09 & 0.28 \\
\hline New Mexico & 0.11 & 0.31 \\
\hline New York & 0.10 & 0.30 \\
\hline North Dakota & 0.10 & 0.30 \\
\hline Oklahoma & 0.10 & 0.31 \\
\hline Oregon & 0.10 & 0.30 \\
\hline Vermont & 0.10 & 0.30 \\
\hline Washington & 0.10 & 0.30 \\
\hline
\end{tabular}


Table 3: Diffusion of Managed Care, 1991-1996

\begin{tabular}{ccc}
\multicolumn{2}{c}{$\begin{array}{c}\text { Average Number } \\
\text { of HMOs serving } \\
\text { a County }\end{array}$} & $\begin{array}{c}\text { Any HMO serving a } \\
\text { County }\end{array}$ \\
\hline 1991 & 2.10 & 0.60 \\
1992 & 2.40 & 0.69 \\
1993 & 2.63 & 0.72 \\
1994 & 3.26 & 0.82 \\
1995 & 3.61 & 0.88 \\
1996 & 4.46 & 0.93 \\
\hline Data Source: Interstudy Directories (1991-1996)
\end{tabular}


Table 4: Effect of HMO Availability on Offer of Health Plan Choice

\begin{tabular}{|c|c|c|c|c|}
\hline & \multicolumn{2}{|c|}{ Full Sample } & \multicolumn{2}{|c|}{ HMO Available in 1996} \\
\hline & Model 1 & Model 2 & Model 3 & Model 4 \\
\hline \multirow[t]{2}{*}{ HMO Available in County-93 } & $0.142 * * *$ & $0.142 * * *$ & $0.150 * * *$ & $0.151^{* * *}$ \\
\hline & {$[0.020]$} & {$[0.020]$} & {$[0.021]$} & {$[0.021]$} \\
\hline \multirow[t]{2}{*}{$\%$ Wage $<\$ 10,000$} & & $-0.001 * * *$ & & $-0.001 * * *$ \\
\hline & & {$[0.000]$} & & {$[0.000]$} \\
\hline \multirow[t]{2}{*}{$\%$ Wage $\$ 10-14,000$} & & $-0.001 * * *$ & & $-0.001 * * *$ \\
\hline & & {$[0.000]$} & & {$[0.000]$} \\
\hline \multirow[t]{2}{*}{$\%$ Wage $\$ 14-20,000$} & & -0.001 & & $-0.001^{*}$ \\
\hline & & {$[0.000]$} & & {$[0.000]$} \\
\hline \multirow[t]{2}{*}{ 51-100 employees } & $0.080 * * *$ & $0.081 * * *$ & $0.083 * * *$ & $0.083 * * *$ \\
\hline & {$[0.016]$} & {$[0.016]$} & {$[0.017]$} & {$[0.017]$} \\
\hline \multirow[t]{2}{*}{ 101-250 employees } & $0.169 * * *$ & $0.170 * * *$ & $0.169 * * *$ & $0.170 * * *$ \\
\hline & {$[0.019]$} & {$[0.019]$} & {$[0.019]$} & {$[0.019]$} \\
\hline \multirow[t]{2}{*}{$250+$ employees } & $0.335 * * *$ & $0.330 * * *$ & $0.337 * * *$ & $0.332 * * *$ \\
\hline & {$[0.023]$} & {$[0.023]$} & {$[0.023]$} & {$[0.023]$} \\
\hline \multirow[t]{2}{*}{ Part of a larger firm } & $0.124 * * *$ & $0.123 * * *$ & $0.124 * * *$ & $0.124 * * *$ \\
\hline & {$[0.014]$} & [0.014] & {$[0.014]$} & {$[0.014]$} \\
\hline \multirow[t]{2}{*}{ For Profit } & $-0.039^{*}$ & $-0.042 *$ & $-0.043^{*}$ & $-0.046^{*}$ \\
\hline & {$[0.023]$} & {$[0.023]$} & {$[0.024]$} & {$[0.024]$} \\
\hline \multirow[t]{2}{*}{ Health Expenditure Variation } & $0.182 * *$ & $0.174^{* *}$ & $0.181 * *$ & $0.169^{* *}$ \\
\hline & {$[0.081]$} & {$[0.081]$} & {$[0.082]$} & {$[0.082]$} \\
\hline \multirow[t]{2}{*}{$\%$ Male $<25$ years } & -0.018 & 0.005 & -0.021 & 0.003 \\
\hline & {$[0.052]$} & {$[0.053]$} & {$[0.053]$} & {$[0.053]$} \\
\hline \multirow[t]{2}{*}{$\%$ Male $>55$} & 0.18 & 0.186 & 0.148 & 0.155 \\
\hline & {$[0.122]$} & {$[0.123]$} & {$[0.124]$} & {$[0.125]$} \\
\hline \multirow[t]{2}{*}{$\%$ Female $<25$ years } & 0.009 & 0.05 & -0.007 & 0.036 \\
\hline & {$[0.056]$} & {$[0.058]$} & {$[0.057]$} & {$[0.058]$} \\
\hline \multirow[t]{2}{*}{$\%$ Female $25-54$} & $0.077^{*}$ & $0.086^{* *}$ & $0.083^{*}$ & $0.093^{* *}$ \\
\hline & {$[0.042]$} & {$[0.042]$} & {$[0.043]$} & {$[0.043]$} \\
\hline \multirow[t]{2}{*}{$\%$ Female $>55$} & 0.061 & 0.091 & 0.082 & 0.114 \\
\hline & {$[0.123]$} & {$[0.123]$} & {$[0.126]$} & {$[0.127]$} \\
\hline \multirow[t]{2}{*}{ County Population $10,000 \mathrm{~s}$} & 0.000 & 0.000 & 0.000 & 0.000 \\
\hline & {$[0.000]$} & {$[0.000]$} & {$[0.000]$} & {$[0.000]$} \\
\hline \multirow[t]{2}{*}{ County Per Capita Income $1,000 \mathrm{~s}$} & 0.003 & 0.002 & 0.003 & 0.002 \\
\hline & {$[0.002]$} & {$[0.002]$} & {$[0.002]$} & {$[0.002]$} \\
\hline \multirow[t]{2}{*}{ County per capita Medicaid discharges } & $-0.004 * * *$ & $-0.004 * * *$ & $-0.004 * * *$ & $-0.004 * * *$ \\
\hline & {$[0.001]$} & {$[0.001]$} & {$[0.001]$} & {$[0.001]$} \\
\hline \multirow[t]{2}{*}{ Teaching Hospitals } & $0.014 * *$ & $0.014 * *$ & $0.015 * *$ & $0.015 * *$ \\
\hline & {$[0.006]$} & {$[0.006]$} & {$[0.006]$} & {$[0.006]$} \\
\hline \multirow[t]{2}{*}{ CMS wage index } & 0.000 & 0.000 & 0.000 & 0.000 \\
\hline & {$[0.001]$} & {$[0.001]$} & {$[0.001]$} & {$[0.001]$} \\
\hline \multirow[t]{2}{*}{ Constant } & -0.029 & 0.016 & -0.025 & 0.024 \\
\hline & {$[0.077]$} & {$[0.079]$} & {$[0.079]$} & {$[0.080]$} \\
\hline Observations & 4549 & 4549 & 4399 & 4399 \\
\hline R-squared & 0.16 & 0.17 & 0.16 & 0.16 \\
\hline
\end{tabular}

Robust standard errors in brackets

* significant at $10 \%$; * significant at $5 \% ; * * *$ significant at $1 \%$

All models include industry and state fixed effects 
Table 5: Effect of Choice on Average Premiums

\begin{tabular}{|c|c|c|c|c|c|c|c|}
\hline & \multicolumn{3}{|c|}{ OLS } & \multicolumn{4}{|c|}{ IV } \\
\hline & \multirow[b]{2}{*}{ Model 1} & \multirow[b]{2}{*}{ Model 2} & \multirow[b]{2}{*}{ Model 3} & \multicolumn{2}{|c|}{ Full Sample } & \multicolumn{2}{|c|}{ HMO Available in 1996} \\
\hline & & & & Model 4 & Model 5 & Model 6 & Model 7 \\
\hline \multirow[t]{2}{*}{ Offers Choice } & 4.878 & 3.789 & 2.621 & $-101.282^{* *}$ & -53.874 & $-87.145^{* *}$ & -39.035 \\
\hline & [3.359] & [3.352] & [2.883] & {$[43.080]$} & [44.105] & {$[42.850]$} & {$[45.145]$} \\
\hline \multirow[t]{2}{*}{$\%$ with family coverage } & & & $235.188 * * *$ & & $242.310^{* * *}$ & & $240.302 * * *$ \\
\hline & & & {$[6.142]$} & & {$[8.508]$} & & {$[8.873]$} \\
\hline \multirow[t]{2}{*}{$\%$ enrolled in $\mathrm{HMO}$} & & & $-19.401 * * *$ & & 1.843 & & -4.033 \\
\hline & & & {$[3.268]$} & & {$[17.002]$} & & {$[17.320]$} \\
\hline \multirow[t]{2}{*}{$\%$ Wage $<\$ 10,000$} & & $-0.178 * *$ & & & & & \\
\hline & & {$[0.082]$} & & & & & \\
\hline \multirow[t]{2}{*}{$\%$ Wage $\$ 10-14,000$} & & $-0.429 * * *$ & & & & & \\
\hline & & {$[0.063]$} & & & & & \\
\hline \multirow[t]{2}{*}{$\%$ Wage $\$ 14-20,000$} & & $-0.195 * *$ & & & & & \\
\hline & & {$[0.078]$} & & & & & \\
\hline \multirow[t]{2}{*}{ 51-100 employees } & $-6.462 *$ & -6.002 & $-6.173 * *$ & 1.998 & -1.797 & 0.116 & -3.586 \\
\hline & {$[3.755]$} & {$[3.750]$} & {$[3.037]$} & {$[5.352]$} & [4.547] & {$[5.386]$} & [4.678] \\
\hline \multirow[t]{2}{*}{ 101-250 employees } & 1.248 & 2.014 & -3.14 & $19.538^{* *}$ & 5.881 & $17.012 * *$ & 3.541 \\
\hline & {$[4.166]$} & [4.138] & [3.501] & {$[8.651]$} & {$[7.725]$} & {$[8.580]$} & [7.818] \\
\hline \multirow[t]{2}{*}{$250+$ employees } & $14.162^{* *}$ & $13.100^{* *}$ & 3.208 & $49.955 * * *$ & 20.546 & $45.600 * * *$ & 15.861 \\
\hline & {$[5.694]$} & {$[5.682]$} & [4.984] & {$[15.761]$} & [14.331] & {$[15.769]$} & [14.678] \\
\hline \multirow[t]{2}{*}{ Part of a larger firm } & $21.230 * * *$ & $20.975 * * *$ & $8.150 * * *$ & $34.530 * * *$ & $15.497 * *$ & $34.288 * * *$ & $13.972 * *$ \\
\hline & {$[3.255]$} & [3.239] & {$[2.723]$} & {$[6.453]$} & {$[6.362]$} & [6.456] & [6.509] \\
\hline \multirow[t]{2}{*}{ For Profit } & $-12.247 * *$ & $-12.847 * * *$ & $-18.210 * * *$ & $-16.355^{* * *}$ & $-19.879 * * *$ & $-15.938 * * *$ & $-18.926 * * *$ \\
\hline & {$[5.008]$} & [4.974] & [3.987] & [5.728] & [4.299] & [5.709] & {$[4.321]$} \\
\hline \multirow[t]{2}{*}{ Health Expenditure Variation } & 27.377 & 25.342 & 13.104 & $46.964 * *$ & 24.143 & $43.151^{*}$ & 19.808 \\
\hline & [19.285] & [19.228] & {$[15.940]$} & {$[22.525]$} & [18.661] & [22.484] & [18.883] \\
\hline$\%$ Male $<25$ years & $-43.552 * * *$ & $-36.703 * * *$ & $-19.844 *$ & $-45.775 * * *$ & $-19.950 *$ & $-45.955 * * *$ & $-20.200 *$ \\
\hline & {$[12.706]$} & [12.705] & {$[10.274]$} & [13.516] & [10.467] & [13.415] & {$[10.446]$} \\
\hline$\%$ Male $>55$ & $65.704 * *$ & $65.778^{* *}$ & $46.276^{* *}$ & $84.790 * * *$ & $53.660 * *$ & $78.024 * * *$ & $49.839 * *$ \\
\hline & [26.901] & [26.179] & {$[21.565]$} & [30.490] & [23.198] & [29.986] & [22.968] \\
\hline$\%$ Female $<25$ years & $-44.413 * * *$ & $-32.489 * * *$ & -13.023 & $-43.434 * * *$ & -12.98 & $-49.602 * * *$ & -15.418 \\
\hline & {$[12.301]$} & {$[12.307]$} & [9.872] & {$[13.694]$} & {$[10.407]$} & {$[13.631]$} & {$[10.557]$} \\
\hline$\%$ Female $25-54$ & 0.908 & 5.268 & $23.570 * * *$ & 8.52 & $27.326^{* * *}$ & 10.171 & $27.528 * * *$ \\
\hline & [9.906] & {$[9.853]$} & {$[8.258]$} & {$[11.351]$} & {$[9.038]$} & {$[11.505]$} & {$[9.291]$} \\
\hline$\%$ Female $>55$ & $-48.463 *$ & -33.483 & -0.011 & -43.373 & 2.168 & -37.019 & 2.805 \\
\hline & {$[25.530]$} & {$[25.230]$} & [19.995] & {$[28.536]$} & [21.209] & {$[28.865]$} & [21.629] \\
\hline County Population $10,000 \mathrm{~s}$ & 0.03 & 0.018 & 0.04 & 0.051 & 0.046 & 0.034 & 0.042 \\
\hline & {$[0.091]$} & {$[0.091]$} & {$[0.077]$} & {$[0.100]$} & {$[0.081]$} & [0.099] & {$[0.080]$} \\
\hline County Per Capita Income $1,000 \mathrm{~s}$ & 0.346 & 0.177 & $0.751^{*}$ & 0.517 & $0.961 * *$ & 0.396 & $0.854 * *$ \\
\hline & {$[0.459]$} & [0.459] & {$[0.390]$} & {$[0.498]$} & {$[0.428]$} & [0.493] & {$[0.432]$} \\
\hline County per capita Medicaid discharges & $0.455^{*}$ & $0.459 *$ & 0.02 & -0.002 & -0.169 & 0.016 & -0.117 \\
\hline & {$[0.251]$} & {$[0.250]$} & {$[0.206]$} & {$[0.332]$} & {$[0.255]$} & {$[0.332]$} & {$[0.259]$} \\
\hline Teaching Hospitals & -1.989 & -1.895 & -0.459 & -0.142 & 0.24 & -0.142 & 0.101 \\
\hline & {$[1.425]$} & [1.418] & [1.209] & {$[1.762]$} & [1.369] & [1.733] & [1.354] \\
\hline CMS wage index & $0.453 * *$ & $0.424 * *$ & $0.580 * * *$ & $0.587 * * *$ & $0.588 * * *$ & $0.644 * * *$ & $0.612 * * *$ \\
\hline & {$[0.199]$} & {$[0.200]$} & {$[0.171]$} & {$[0.225]$} & {$[0.178]$} & {$[0.222]$} & {$[0.178]$} \\
\hline Constant & $179.964 * * *$ & $197.459 * * *$ & $73.744 * * *$ & $180.205^{* * *}$ & $67.100 * * *$ & $175.194 * * *$ & $66.936 * * *$ \\
\hline & {$[18.391]$} & {$[18.726]$} & [15.139] & [19.935] & {$[16.361]$} & [19.792] & {$[16.255]$} \\
\hline Observations & 4549 & 4549 & 4549 & 4549 & 4549 & 4399 & 4399 \\
\hline R-squared & 0.06 & 0.07 & 0.36 & & 0.3 & & 0.32 \\
\hline
\end{tabular}


Table 6: Effect of Choice on Average Employer Premium Contributions

OLS

\begin{tabular}{|c|c|c|c|c|c|c|c|}
\hline & & \\
\hline & \multirow[b]{2}{*}{ Model 1} & \multirow[b]{2}{*}{ Model 2} & \multirow[b]{2}{*}{ Model 3} & \multicolumn{2}{|c|}{ Full Sample } & \multicolumn{2}{|c|}{ HMO Available in 1996} \\
\hline & & & & Model 4 & Model 5 & Model 6 & Model 7 \\
\hline \multirow[t]{2}{*}{ Offers Choice } & 1.317 & 0.08 & 2.607 & $-73.657 *$ & -31.254 & -57.056 & -11.728 \\
\hline & {$[3.170]$} & [3.157] & [2.964] & {$[39.080]$} & [44.041] & {$[38.662]$} & [44.847] \\
\hline \multirow[t]{2}{*}{$\%$ with family coverage } & & & $160.449 * * *$ & & $164.718^{* * *}$ & & $160.831 * * *$ \\
\hline & & & {$[6.594]$} & & [8.739] & & {$[8.980]$} \\
\hline \multirow[t]{2}{*}{$\%$ enrolled in $\mathrm{HMO}$} & & & $-26.797 * * *$ & & -14.064 & & -21.733 \\
\hline & & & {$[3.597]$} & & {$[16.950]$} & & {$[17.202]$} \\
\hline \multirow[t]{2}{*}{$\%$ Wage $<\$ 10,000$} & & $-0.198 * *$ & & & & & \\
\hline & & {$[0.078]$} & & & & & \\
\hline \multirow[t]{2}{*}{$\%$ Wage $\$ 10-14,000$} & & $-0.480 * * *$ & & & & & \\
\hline & & {$[0.059]$} & & & & & \\
\hline \multirow[t]{2}{*}{$\%$ Wage $\$ 14-20,000$} & & $-0.298 * * *$ & & & & & \\
\hline & & {$[0.074]$} & & & & & \\
\hline \multirow[t]{2}{*}{ 51-100 employees } & -5.101 & -4.697 & -5.049 & 0.874 & -2.426 & -0.862 & -4.277 \\
\hline & {$[3.563]$} & {$[3.550]$} & [3.215] & [4.919] & {$[4.710]$} & [4.928] & [4.824] \\
\hline \multirow[t]{2}{*}{ 101-250 employees } & 2.295 & 3.138 & -0.833 & $15.212 *$ & 4.574 & 12.395 & 1.636 \\
\hline & [3.907] & {$[3.870]$} & [3.614] & [7.929] & [7.943] & {$[7.871]$} & [8.053] \\
\hline \multirow[t]{2}{*}{$250+$ employees } & $18.641 * * *$ & $17.453 * * *$ & $11.056^{* *}$ & $43.919^{* * *}$ & 21.448 & $39.210^{* * *}$ & 16.013 \\
\hline & {$[5.133]$} & {$[5.112]$} & [4.719] & {$[14.488]$} & {$[14.556]$} & {$[14.448]$} & [14.897] \\
\hline \multirow[t]{2}{*}{ Part of a larger firm } & $22.056^{* * *}$ & $21.701^{* * *}$ & $12.360^{* * *}$ & $31.449 * * *$ & $16.764 * * *$ & $30.088^{* * *}$ & $14.213 * *$ \\
\hline & {$[3.024]$} & {$[3.000]$} & {$[2.799]$} & {$[5.740]$} & {$[6.221]$} & {$[5.726]$} & {$[6.362]$} \\
\hline \multirow[t]{2}{*}{ For Profit } & $-27.876^{* * *}$ & $-28.660 * * *$ & $-32.267 * * *$ & $-30.777 * * *$ & $-33.267 * * *$ & $-29.848 * * *$ & $-31.977 * * *$ \\
\hline & [4.916] & {$[4.858]$} & [4.403] & {$[5.313]$} & [4.564] & {$[5.297]$} & [4.616] \\
\hline \multirow[t]{2}{*}{ Health Expenditure Variation } & 19.813 & 17.121 & 8.896 & 33.646 & 15.512 & 29.933 & 10.843 \\
\hline & {$[18.898]$} & {$[18.940]$} & {$[17.334]$} & [20.938] & {$[19.458]$} & [20.899] & [19.711] \\
\hline$\%$ Male $<25$ years & $-35.929 * * *$ & $-28.318^{* *}$ & $-19.919^{*}$ & $-37.500 * * *$ & $-19.982 *$ & $-38.226^{* * *}$ & $-20.961^{*}$ \\
\hline & {$[12.062]$} & {$[12.044]$} & {$[11.280]$} & {$[12.441]$} & {$[11.342]$} & {$[12.354]$} & {$[11.378]$} \\
\hline$\%$ Male $>55$ & $59.615^{* *}$ & $59.228 * *$ & $47.202 *$ & $73.094 * * *$ & $51.627 * *$ & $67.737 * *$ & $48.856^{*}$ \\
\hline & {$[27.878]$} & {$[27.347]$} & [25.079] & {$[27.841]$} & {$[25.066]$} & {$[28.115]$} & {$[25.692]$} \\
\hline$\%$ Female $<25$ years & $-43.997 * * *$ & $-31.359 * * *$ & $-21.722 * *$ & $-43.306 * * *$ & $-21.696^{* *}$ & $-49.152 * * *$ & $-24.890 * *$ \\
\hline & {$[11.981]$} & {$[12.028]$} & {$[10.821]$} & [12.706] & {$[10.993]$} & [12.634] & {$[11.171]$} \\
\hline$\%$ Female $25-54$ & -9.019 & -4.33 & 6.844 & -3.643 & 9.096 & -3.122 & 8.316 \\
\hline & [9.633] & [9.588] & [8.828] & {$[10.591]$} & {$[9.476]$} & {$[10.785]$} & [9.814] \\
\hline$\%$ Female $>55$ & $-58.272 * *$ & $-41.547^{*}$ & -24.114 & $-54.677 * *$ & -22.808 & $-51.319 * *$ & -23.593 \\
\hline & {$[23.961]$} & {$[23.704]$} & {$[20.644]$} & {$[25.491]$} & [21.007] & {$[25.790]$} & {$[21.561]$} \\
\hline County Population $10,000 \mathrm{~s}$ & -0.004 & -0.019 & 0.005 & 0.011 & 0.009 & 0 & 0.007 \\
\hline & {$[0.085]$} & {$[0.084]$} & {$[0.079]$} & {$[0.090]$} & {$[0.081]$} & {$[0.089]$} & {$[0.080]$} \\
\hline County Per Capita Income $1,000 \mathrm{~s}$ & -0.061 & -0.261 & 0.144 & 0.06 & 0.27 & -0.027 & 0.164 \\
\hline & {$[0.484]$} & {$[0.482]$} & {$[0.442]$} & {$[0.501]$} & {$[0.465]$} & {$[0.498]$} & {$[0.469]$} \\
\hline County per capita Medicaid discharges & 0.314 & 0.314 & -0.013 & -0.009 & -0.126 & 0.017 & -0.076 \\
\hline & [0.245] & {$[0.244]$} & {$[0.220]$} & {$[0.305]$} & {$[0.261]$} & {$[0.305]$} & {$[0.265]$} \\
\hline Teaching Hospitals & -0.924 & -0.806 & 0.275 & 0.381 & 0.694 & 0.257 & 0.486 \\
\hline & {$[1.331]$} & [1.324] & [1.229] & {$[1.575]$} & {$[1.351]$} & {$[1.548]$} & [1.341] \\
\hline CMS wage index & $0.863 * * *$ & $0.833 * * *$ & $0.987 * * *$ & $0.958 * * *$ & $0.992 * * *$ & $0.974 * * *$ & $0.995 * * *$ \\
\hline & {$[0.194]$} & {$[0.195]$} & {$[0.182]$} & {$[0.212]$} & {$[0.184]$} & {$[0.211]$} & {$[0.186]$} \\
\hline Constant & $80.967 * * *$ & $102.664 * * *$ & 10.705 & $81.137^{* * *}$ & 6.722 & $79.183 * * *$ & 9.752 \\
\hline & {$[17.569]$} & [17.888] & {$[15.962]$} & [18.348] & [17.131] & {$[18.245]$} & {$[17.108]$} \\
\hline Observations & 4549 & 4549 & 4549 & 4549 & 4549 & 4399 & 4399 \\
\hline R-squared & 0.08 & 0.09 & 0.24 & & 0.22 & 0.01 & 0.23 \\
\hline
\end{tabular}


Table 7: Effect of Choice on Average Employee Premium Contributions

\begin{tabular}{|c|c|c|c|c|c|c|c|}
\hline & \multicolumn{3}{|c|}{ OLS } & \multicolumn{4}{|c|}{ IV } \\
\hline & \multirow[b]{2}{*}{ Model 1} & \multirow[b]{2}{*}{ Model 2} & \multirow[b]{2}{*}{ Model 3} & \multicolumn{2}{|c|}{ Full Sample } & \multicolumn{2}{|c|}{ HMO Available in 1996} \\
\hline & & & & Model 4 & Model 5 & Model 6 & Model 7 \\
\hline \multirow[t]{2}{*}{ Offers Choice } & 3.561 & 3.709 & 0.014 & -27.625 & -22.621 & -30.089 & -27.308 \\
\hline & [2.312] & [2.320] & {$[2.324]$} & {$[27.755]$} & {$[34.742]$} & {$[27.851]$} & [35.322] \\
\hline \multirow{2}{*}{$\%$ with family coverage } & & & $74.739 * * *$ & & $77.592 * * *$ & & $79.471 * * *$ \\
\hline & & & {$[5.448]$} & & {$[6.728]$} & & [6.969] \\
\hline \multirow[t]{2}{*}{$\%$ enrolled in $\mathrm{HMO}$} & & & $7.396 * * *$ & & 15.907 & & 17.699 \\
\hline & & & {$[2.846]$} & & {$[13.473]$} & & {$[13.665]$} \\
\hline \multirow[t]{2}{*}{$\%$ Wage $<\$ 10,000$} & & 0.019 & & & & & \\
\hline & & {$[0.058]$} & & & & & \\
\hline \multirow[t]{2}{*}{$\%$ Wage $\$ 10-14,000$} & & 0.051 & & & & & \\
\hline & & {$[0.047]$} & & & & & \\
\hline \multirow[t]{2}{*}{$\%$ Wage $\$ 14-20,000$} & & $0.103 * *$ & & & & & \\
\hline & & {$[0.053]$} & & & & & \\
\hline \multirow[t]{2}{*}{ 51-100 employees } & -1.361 & -1.305 & -1.124 & 1.124 & 0.63 & 0.977 & 0.692 \\
\hline & [2.698] & [2.703] & [2.608] & {$[3.520]$} & {$[3.766]$} & [3.633] & [3.911] \\
\hline \multirow[t]{2}{*}{ 101-250 employees } & -1.047 & -1.124 & -2.307 & 4.326 & 1.307 & 4.617 & 1.905 \\
\hline & [2.978] & [2.976] & [2.882] & {$[5.673]$} & {$[6.278]$} & {$[5.683]$} & [6.332] \\
\hline \multirow[t]{2}{*}{$250+$ employees } & -4.479 & -4.352 & $-7.848 * *$ & 6.036 & -0.901 & 6.39 & -0.153 \\
\hline & [3.651] & [3.660] & [3.614] & [9.893] & [11.120] & [10.009] & [11.384] \\
\hline \multirow[t]{2}{*}{ Part of a larger firm } & -0.826 & -0.726 & $-4.210^{*}$ & 3.081 & -1.266 & 4.2 & -0.241 \\
\hline & [2.261] & {$[2.266]$} & [2.187] & [4.145] & [5.046] & [4.228] & [5.192] \\
\hline \multirow[t]{2}{*}{ For Profit } & $15.629 * * *$ & $15.813 * * *$ & $14.057 * * *$ & $14.423 * * *$ & $13.388 * * *$ & $13.910 * * *$ & $13.051 * * *$ \\
\hline & {$[3.622]$} & {$[3.641]$} & {$[3.525]$} & {$[3.795]$} & [3.634] & [3.918] & {$[3.744]$} \\
\hline \multirow[t]{2}{*}{ Health Expenditure Variation } & 7.564 & 8.221 & 4.208 & 13.318 & 8.631 & 13.218 & 8.965 \\
\hline & {$[13.555]$} & [13.549] & [13.028] & {$[14.850]$} & {$[14.925]$} & [15.107] & {$[15.242]$} \\
\hline$\%$ Male $<25$ years & -7.622 & -8.385 & 0.075 & -8.276 & 0.033 & -7.729 & 0.76 \\
\hline & [9.321] & [9.447] & [8.854] & [9.464] & [8.891] & [9.599] & [9.023] \\
\hline$\%$ Male $>55$ & 6.089 & 6.55 & -0.926 & 11.696 & 2.033 & 10.287 & 0.983 \\
\hline & [19.545] & [19.664] & [18.947] & [21.514] & {$[20.250]$} & [21.912] & {$[20.675]$} \\
\hline$\%$ Female $<25$ years & -0.415 & -1.13 & 8.699 & -0.128 & 8.716 & -0.451 & 9.471 \\
\hline & [8.591] & [8.805] & [8.311] & {$[8.775]$} & {$[8.420]$} & {$[9.055]$} & {$[8.747]$} \\
\hline$\%$ Female $25-54$ & 9.927 & 9.598 & $16.725 * *$ & $12.163 *$ & $18.230 * * *$ & $13.292 *$ & $19.212 * * *$ \\
\hline & {$[6.676]$} & [6.698] & {$[6.492]$} & [7.084] & [6.917] & {$[7.357]$} & [7.238] \\
\hline$\%$ Female $>55$ & 9.809 & 8.064 & 24.103 & 11.304 & 24.976 & 14.3 & 26.398 \\
\hline & [18.311] & {$[18.352]$} & [18.039] & {$[18.795]$} & {$[18.344]$} & {$[19.533]$} & [19.101] \\
\hline County Population $10,000 \mathrm{~s}$ & 0.034 & 0.037 & 0.035 & 0.041 & 0.038 & 0.034 & 0.036 \\
\hline & {$[0.067]$} & {$[0.067]$} & {$[0.064]$} & {$[0.068]$} & {$[0.065]$} & {$[0.069]$} & {$[0.066]$} \\
\hline County Per Capita Income 1,000 s & 0.407 & 0.438 & $0.607 * *$ & 0.457 & $0.691 * *$ & 0.423 & $0.690 * *$ \\
\hline & {$[0.297]$} & {$[0.297]$} & {$[0.297]$} & {$[0.307]$} & {$[0.330]$} & {$[0.314]$} & {$[0.340]$} \\
\hline County per capita Medicaid discharges & 0.141 & 0.145 & 0.033 & 0.007 & -0.043 & -0.001 & -0.041 \\
\hline & {$[0.171]$} & {$[0.171]$} & {$[0.167]$} & {$[0.212]$} & {$[0.205]$} & {$[0.219]$} & {$[0.212]$} \\
\hline Teaching Hospitals & -1.065 & -1.088 & -0.734 & -0.522 & -0.454 & -0.399 & -0.386 \\
\hline & {$[0.990]$} & {$[0.992]$} & {$[0.960]$} & {$[1.123]$} & {$[1.063]$} & {$[1.137]$} & {$[1.077]$} \\
\hline CMS wage index & $-0.410 * * *$ & $-0.410 * * *$ & $-0.408 * * *$ & $-0.370 * * *$ & $-0.404 * * *$ & $-0.330 * *$ & $-0.383 * * *$ \\
\hline & {$[0.136]$} & {$[0.136]$} & {$[0.132]$} & {$[0.143]$} & [0.134] & {$[0.145]$} & [0.137] \\
\hline Constant & $98.997 * * *$ & $94.795 * * *$ & $63.040 * * *$ & $99.068 * * *$ & $60.377 * * *$ & $96.011 * * *$ & $57.184 * * *$ \\
\hline & {$[12.490]$} & {$[12.685]$} & {$[11.861]$} & {$[12.716]$} & [12.619] & [12.914] & {$[12.689]$} \\
\hline Observations & 4549 & 4549 & 4549 & 4549 & 4549 & 4399 & 4399 \\
\hline R-squared & 0.03 & 0.03 & 0.09 & & 0.07 & & 0.07 \\
\hline
\end{tabular}

Robust standard errors in brackets

* significant at $10 \%$;* significant at $5 \% ; * * *$ significant at $1 \%$

all models include state and industry fixed effects 
Table 8: Effect of Choice on Average Employer Share

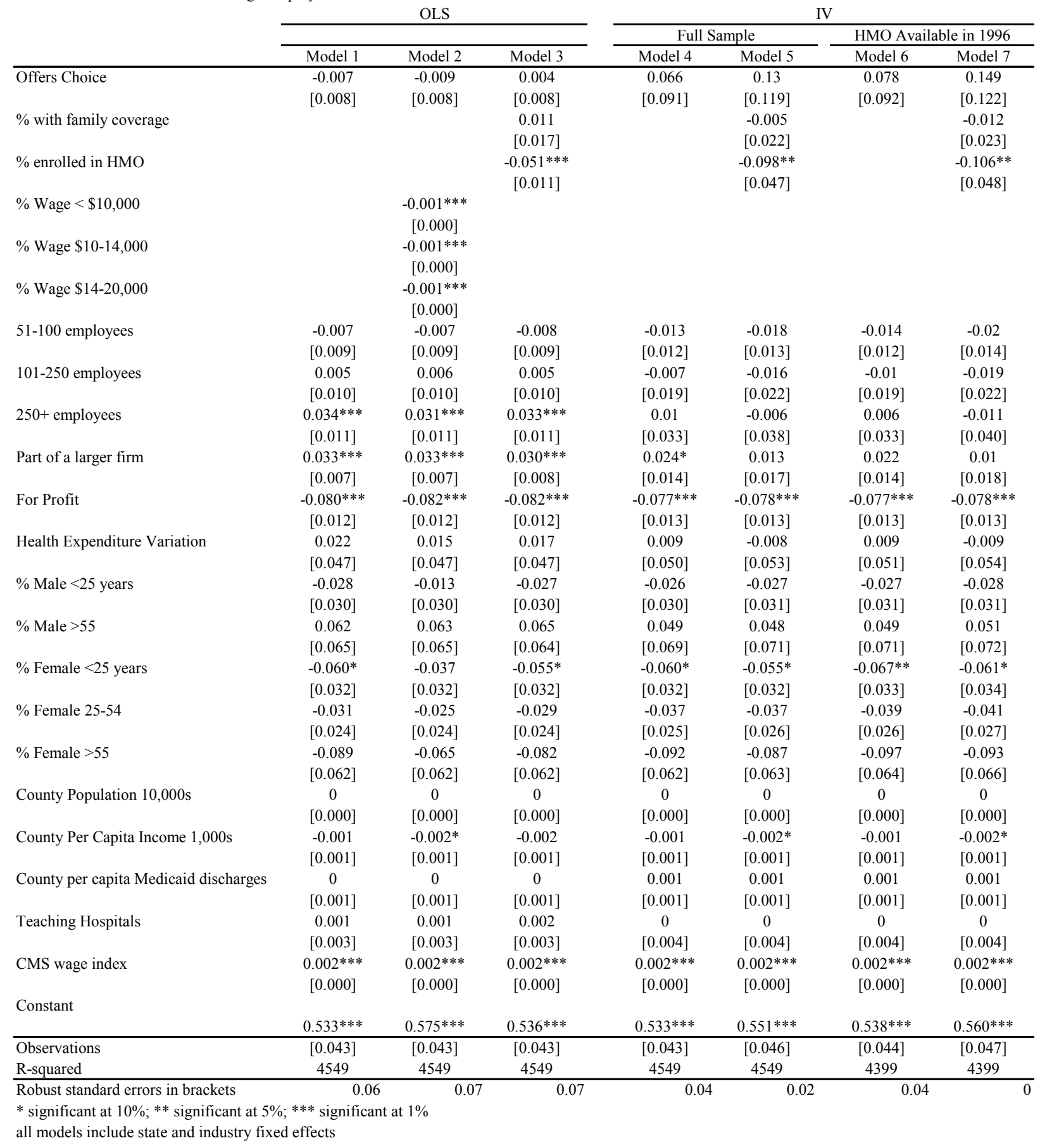


Table 9: Effect of Choice on Average Premiums - Single Coverage

\begin{tabular}{|c|c|c|c|c|c|c|c|}
\hline & \multicolumn{3}{|c|}{ OLS } & \multicolumn{4}{|c|}{ IV } \\
\hline & \multirow[b]{2}{*}{ Model 1} & \multirow[b]{2}{*}{ Model 2} & \multirow[b]{2}{*}{ Model 3} & \multicolumn{2}{|c|}{ Full Sample } & \multicolumn{2}{|c|}{ HMO Available in 1996} \\
\hline & & & & Model 4 & Model 5 & Model 6 & Model 7 \\
\hline \multirow[t]{2}{*}{ Offers Choice } & $-5.291 * * *$ & $-5.426 * * *$ & -2.181 & $-41.150 * *$ & -40.737 & -31.789 & -27.85 \\
\hline & {$[1.807]$} & {$[1.805]$} & {$[1.806]$} & {$[20.870]$} & {$[27.617]$} & {$[20.657]$} & {$[27.450]$} \\
\hline \multirow[t]{2}{*}{$\%$ enrolled in $\mathrm{HMO}$} & & & $-14.903 * * *$ & & -0.621 & & -5.71 \\
\hline & & & {$[1.973]$} & & {$[10.491]$} & & {$[10.335]$} \\
\hline \multirow[t]{2}{*}{$\%$ Wage $<\$ 10,000$} & & 0.005 & & & & & \\
\hline & & {$[0.041]$} & & & & & \\
\hline \multirow[t]{2}{*}{$\%$ Wage $\$ 10-14,000$} & & $-0.077 * *$ & & & & & \\
\hline & & {$[0.036]$} & & & & & \\
\hline \multirow[t]{2}{*}{$\%$ Wage $\$ 14-20,000$} & & -0.03 & & & & & \\
\hline & & {$[0.038]$} & & & & & \\
\hline \multirow[t]{2}{*}{ 51-100 employees } & -3.08 & -3.01 & $-3.240 *$ & -0.222 & -0.252 & -0.932 & -1.214 \\
\hline & [1.909] & [1.910] & [1.904] & {$[2.521]$} & {$[2.847]$} & [2.563] & {$[2.891]$} \\
\hline \multirow[t]{2}{*}{ 101-250 employees } & -2.391 & -2.245 & -2.539 & 3.788 & 3.733 & 2.43 & 1.907 \\
\hline & [2.233] & [2.231] & {$[2.227]$} & [4.172] & [4.947] & [4.135] & [4.901] \\
\hline \multirow[t]{2}{*}{$250+$ employees } & 0.257 & 0.185 & 0.134 & $12.347 *$ & 12.246 & 9.2 & 8.212 \\
\hline & [3.054] & [3.052] & [3.042] & {$[7.421]$} & [8.945] & [7.345] & [8.905] \\
\hline \multirow[t]{2}{*}{ Part of a larger firm } & $5.964 * * *$ & $5.904 * * *$ & $5.115 * * *$ & $10.457 * * *$ & $10.386^{* *}$ & $9.174 * * *$ & $8.491 * *$ \\
\hline & [1.739] & {$[1.742]$} & {$[1.734]$} & [3.142] & {$[4.151]$} & [3.115] & [4.134] \\
\hline \multirow[t]{2}{*}{ For Profit } & $-9.649 * * *$ & $-9.662 * * *$ & $-10.003 * * *$ & $-11.037 * * *$ & $-11.041 * * *$ & $-10.454 * * *$ & $-10.493 * * *$ \\
\hline & {$[2.701]$} & {$[2.707]$} & {$[2.682]$} & {$[2.881]$} & {$[2.867]$} & [2.898] & {$[2.857]$} \\
\hline \multirow[t]{2}{*}{ Health Expenditure Variation } & 8.061 & 7.896 & 6.764 & 14.677 & 14.571 & 12.302 & 11.262 \\
\hline & [9.220] & [9.244] & [9.258] & {$[10.415]$} & [11.104] & [10.326] & [11.018] \\
\hline \multirow[t]{2}{*}{$\%$ Male $<25$ years } & $-17.233 * * *$ & $-16.552 * * *$ & $-17.412^{* * *}$ & $-17.984 * * *$ & $-17.985 * * *$ & $-16.996^{* * *}$ & $-16.987 * * *$ \\
\hline & [6.159] & [6.204] & [6.188] & [6.382] & {$[6.379]$} & {$[6.316]$} & {$[6.294]$} \\
\hline \multirow[t]{2}{*}{$\%$ Male $>55$} & $32.734 * *$ & $32.427 * *$ & $33.657 * *$ & $39.181 * *$ & $39.168 * *$ & $36.349^{* *}$ & $36.344 * *$ \\
\hline & {$[14.288]$} & {$[14.276]$} & {$[14.334]$} & {$[15.741]$} & {$[15.786]$} & {$[15.598]$} & {$[15.527]$} \\
\hline$\%$ Female $<25$ years & -2.036 & -0.868 & -1.09 & -1.705 & -1.668 & -2.716 & -2.301 \\
\hline & {$[6.066]$} & [6.124] & {$[6.061]$} & {$[6.422]$} & [6.453] & {$[6.451]$} & {$[6.488]$} \\
\hline$\%$ Female $25-54$ & $14.481 * * *$ & $15.169 * * *$ & $14.924 * * *$ & $17.053 * * *$ & $17.051 * * *$ & $17.508^{* * *}$ & $17.454 * * *$ \\
\hline & {$[4.895]$} & [4.913] & {$[4.877]$} & {$[5.337]$} & {$[5.340]$} & {$[5.418]$} & {$[5.410]$} \\
\hline$\%$ Female $>55$ & 17.851 & 20.402 & 19.064 & 19.571 & 19.608 & 20.438 & 20.76 \\
\hline & {$[12.437]$} & {$[12.430]$} & {$[12.417]$} & {$[13.285]$} & {$[13.185]$} & {$[13.490]$} & {$[13.290]$} \\
\hline County Population $10,000 \mathrm{~s}$ & 0.029 & 0.027 & 0.032 & 0.036 & 0.036 & 0.032 & 0.032 \\
\hline & [0.049] & [0.049] & {$[0.048]$} & {$[0.051]$} & {$[0.051]$} & {$[0.051]$} & {$[0.050]$} \\
\hline County Per Capita Income $1,000 \mathrm{~s}$ & $0.466^{*}$ & $0.443^{*}$ & 0.388 & $0.524 *$ & $0.520^{*}$ & $0.487^{*}$ & 0.452 \\
\hline & {$[0.263]$} & {$[0.263]$} & {$[0.262]$} & [0.269] & {$[0.280]$} & [0.269] & {$[0.278]$} \\
\hline County per capita Medicaid discharges & 0.004 & 0.002 & -0.029 & -0.15 & -0.151 & -0.115 & -0.117 \\
\hline & {$[0.125]$} & {$[0.126]$} & {$[0.125]$} & {$[0.152]$} & {$[0.151]$} & {$[0.154]$} & {$[0.151]$} \\
\hline Teaching Hospitals & -0.64 & -0.621 & -0.47 & -0.016 & -0.014 & -0.119 & -0.099 \\
\hline & {$[0.733]$} & {$[0.735]$} & {$[0.726]$} & {$[0.835]$} & {$[0.821]$} & [0.822] & {$[0.802]$} \\
\hline CMS wage index & $0.333 * * *$ & $0.328 * * *$ & $0.374 * * *$ & $0.378 * * *$ & $0.379 * * *$ & $0.374 * * *$ & $0.386 * * *$ \\
\hline & {$[0.112]$} & {$[0.113]$} & {$[0.113]$} & {$[0.120]$} & {$[0.117]$} & {$[0.120]$} & {$[0.117]$} \\
\hline Constant & $106.647^{* * *}$ & $109.199 * * *$ & $109.067 * * *$ & $106.728^{* * *}$ & $106.828^{* * *}$ & $105.780 * * *$ & $106.688^{* * *}$ \\
\hline & [9.753] & [10.003] & [9.675] & [10.047] & [10.161] & [10.045] & {$[10.069]$} \\
\hline Observations & 4549 & 4549 & 4549 & 4549 & 4549 & 4399 & 4399 \\
\hline R-squared & 0.07 & 0.07 & 0.08 & & & 0.02 & 0.04 \\
\hline
\end{tabular}

Robust standard errors in brackets

* significant at $10 \%$;* significant at $5 \%$; ** significant at $1 \%$

all models include state and industry fixed effects 
Table 10: Effect of Choice on Standardized Premiums - Single Coverage

\begin{tabular}{|c|c|c|c|c|}
\hline & \multicolumn{2}{|c|}{ OLS } & \multicolumn{2}{|c|}{ IV } \\
\hline & \multirow[b]{2}{*}{ Model 1} & \multirow[b]{2}{*}{ Model 2} & \multirow{2}{*}{$\frac{\text { Full Sample }}{\text { Model } 4}$} & \multirow{2}{*}{$\begin{array}{l}\text { HMO Available } \\
\text { in } 1996 \\
\text { Model } 6 \\
\end{array}$} \\
\hline & & & & \\
\hline \multirow[t]{2}{*}{ Offers Choice } & $0.312 * * *$ & 0.092 & -1.105 & -0.301 \\
\hline & {$[0.117]$} & {$[0.093]$} & [2.128] & [2.848] \\
\hline \multirow[t]{2}{*}{$\%$ Wage $<\$ 10,000$} & & $-0.024 * * *$ & & \\
\hline & & {$[0.006]$} & & \\
\hline \multirow[t]{2}{*}{$\%$ Wage $\$ 10-14,000$} & & $-0.097 * * *$ & & \\
\hline & & {$[0.004]$} & & \\
\hline \multirow[t]{2}{*}{$\%$ Wage $\$ 14-20,000$} & & $-0.045 * * *$ & & \\
\hline & & {$[0.004]$} & & \\
\hline \multirow[t]{2}{*}{ 51-100 employees } & $-3.392 * * *$ & $-3.298 * * *$ & $-3.280 * * *$ & $-3.341 * * *$ \\
\hline & {$[0.212]$} & [0.199] & {$[0.289]$} & {$[0.344]$} \\
\hline \multirow[t]{2}{*}{ 101-250 employees } & $-2.774 * * *$ & $-2.597 * * *$ & $-2.529 * * *$ & $-2.652 * * *$ \\
\hline & {$[0.204]$} & {$[0.172]$} & {$[0.426]$} & {$[0.513]$} \\
\hline \multirow[t]{2}{*}{$250+$ employees } & $-1.600 * * *$ & $-1.788 * * *$ & -1.122 & -1.397 \\
\hline & {$[0.151]$} & {$[0.087]$} & [0.719] & [0.945] \\
\hline \multirow[t]{2}{*}{ Part of a larger firm } & $-1.972 * * *$ & $-2.039 * * *$ & $-1.795 * * *$ & $-1.894 * * *$ \\
\hline & {$[0.192]$} & {$[0.180]$} & {$[0.377]$} & {$[0.461]$} \\
\hline \multirow[t]{2}{*}{ For Profit } & 0.032 & -0.066 & -0.022 & 0.021 \\
\hline & {$[0.237]$} & {$[0.212]$} & {$[0.279]$} & {$[0.312]$} \\
\hline \multirow[t]{2}{*}{ Health Expenditure Variation } & 2.198 & 1.81 & 2.459 & 2.446 \\
\hline & {$[2.515]$} & {$[2.539]$} & {$[2.644]$} & {$[2.693]$} \\
\hline \multirow[t]{2}{*}{$\%$ Male $<25$ years } & $-20.699 * * *$ & $-19.392 * * *$ & $-20.729 * * *$ & $-20.695 * * *$ \\
\hline & [1.164] & {$[1.140]$} & [1.159] & {$[1.180]$} \\
\hline \multirow[t]{2}{*}{$\%$ Male $>55$} & $47.815^{* * *}$ & $47.673 * * *$ & $48.070 * * *$ & $47.814 * * *$ \\
\hline & {$[1.130]$} & {$[0.981]$} & {$[1.297]$} & {$[1.330]$} \\
\hline \multirow[t]{2}{*}{$\%$ Female $<25$ years } & $-2.189 * * *$ & 0.056 & $-2.176^{* * *}$ & $-2.295 * * *$ \\
\hline & {$[0.806]$} & {$[0.701]$} & {$[0.807]$} & {$[0.832]$} \\
\hline \multirow[t]{2}{*}{$\%$ Female $25-54$} & $12.322 * * *$ & $13.260 * * *$ & $12.423 * * *$ & $12.364 * * *$ \\
\hline & {$[1.002]$} & {$[0.982]$} & {$[1.106]$} & {$[1.195]$} \\
\hline \multirow[t]{2}{*}{$\%$ Female $>55$} & $39.643^{* * *}$ & $42.974 * * *$ & $39.711 * * *$ & $39.796^{* * *}$ \\
\hline & {$[2.445]$} & {$[2.277]$} & {$[2.419]$} & {$[2.487]$} \\
\hline \multirow[t]{2}{*}{ County Population $10,000 \mathrm{~s}$} & $0.006^{*}$ & 0.003 & $0.006^{*}$ & 0.005 \\
\hline & {$[0.003]$} & {$[0.003]$} & {$[0.003]$} & {$[0.004]$} \\
\hline \multirow[t]{2}{*}{ County Per Capita Income 1,000s } & $0.030 *$ & -0.005 & $0.033^{*}$ & 0.031 \\
\hline & {$[0.017]$} & {$[0.014]$} & {$[0.018]$} & {$[0.020]$} \\
\hline County per capita Medicaid discharges & 0.008 & 0.008 & 0.002 & 0.005 \\
\hline & {$[0.016]$} & {$[0.015]$} & {$[0.018]$} & {$[0.020]$} \\
\hline Teaching Hospitals & -0.078 & -0.055 & -0.053 & -0.061 \\
\hline & {$[0.059]$} & {$[0.050]$} & {$[0.073]$} & {$[0.079]$} \\
\hline CMS wage index & $0.025^{*}$ & 0.019 & $0.027 * *$ & $0.027 * *$ \\
\hline & {$[0.013]$} & {$[0.012]$} & {$[0.013]$} & {$[0.013]$} \\
\hline Constant & $138.924 * * *$ & $142.708 * * *$ & $138.927 * * *$ & $138.859 * * *$ \\
\hline & {$[2.033]$} & {$[2.143]$} & {$[2.036]$} & [2.092] \\
\hline Observations & 4549 & 4549 & 4549 & 4399 \\
\hline R-squared & 0.85 & 0.88 & 0.85 & 0.85 \\
\hline
\end{tabular}

Robust standard errors in brackets

* significant at $10 \% ; * *$ significant at 5\%; *** significant at $1 \%$

all models include state and industry fixed effects 
Table 11: Effect of Choice on \% of Employees Covered

\begin{tabular}{|c|c|c|c|c|}
\hline & \multicolumn{2}{|c|}{ OLS } & \multicolumn{2}{|c|}{ IV } \\
\hline & & & \multirow{3}{*}{$\begin{array}{c}\text { Full Sample } \\
\text { Model } 3\end{array}$} & \multirow{3}{*}{$\begin{array}{c}\text { HMO Available } \\
\text { in } 1996 \\
\text { Model } 4\end{array}$} \\
\hline & & & & \\
\hline & Model 1 & Model 2 & & \\
\hline \multirow[t]{2}{*}{ Offers Choice } & $0.056^{* * *}$ & $0.048 * * *$ & 0.045 & 0.079 \\
\hline & {$[0.008]$} & {$[0.008]$} & {$[0.095]$} & {$[0.094]$} \\
\hline \multirow[t]{2}{*}{$\%$ Wage $<\$ 10,000$} & & $-0.003 * * *$ & & \\
\hline & & {$[0.000]$} & & \\
\hline \multirow[t]{2}{*}{$\%$ Wage $\$ 10-14,000$} & & $-0.002 * * *$ & & \\
\hline & & {$[0.000]$} & & \\
\hline \multirow[t]{2}{*}{$\%$ Wage $\$ 14-20,000$} & & $-0.001 * * *$ & & \\
\hline & & {$[0.000]$} & & \\
\hline \multirow[t]{2}{*}{ 51-100 employees } & -0.012 & -0.008 & -0.011 & -0.012 \\
\hline & {$[0.010]$} & [0.009] & {$[0.012]$} & {$[0.013]$} \\
\hline \multirow[t]{2}{*}{ 101-250 employees } & 0.01 & 0.013 & 0.012 & 0.007 \\
\hline & [0.010] & {$[0.010]$} & [0.019] & [0.019] \\
\hline \multirow[t]{2}{*}{$250+$ employees } & $0.039 * * *$ & $0.026^{* *}$ & 0.043 & 0.032 \\
\hline & {$[0.012]$} & {$[0.012]$} & {$[0.034]$} & {$[0.034]$} \\
\hline \multirow[t]{2}{*}{ Part of a larger firm } & $0.047 * * *$ & $0.048 * * *$ & $0.049 * * *$ & $0.043 * * *$ \\
\hline & {$[0.008]$} & {$[0.008]$} & {$[0.014]$} & {$[0.014]$} \\
\hline \multirow[t]{2}{*}{ For Profit } & 0.011 & 0.002 & 0.01 & 0.013 \\
\hline & {$[0.013]$} & {$[0.012]$} & {$[0.013]$} & {$[0.014]$} \\
\hline \multirow[t]{2}{*}{ Health Expenditure Variation } & $0.118 * *$ & $0.099 *$ & $0.121 * *$ & $0.123 * *$ \\
\hline & {$[0.055]$} & {$[0.051]$} & {$[0.058]$} & {$[0.058]$} \\
\hline \multirow[t]{2}{*}{$\%$ Male $<25$ years } & $-0.254 * * *$ & $-0.186 * * *$ & $-0.254 * * *$ & $-0.247 * * *$ \\
\hline & {$[0.035]$} & {$[0.033]$} & {$[0.035]$} & {$[0.035]$} \\
\hline \multirow[t]{2}{*}{$\%$ Male $>55$} & 0.04 & 0.067 & 0.042 & 0.019 \\
\hline & {$[0.074]$} & {$[0.067]$} & {$[0.075]$} & {$[0.075]$} \\
\hline \multirow[t]{2}{*}{$\%$ Female $<25$ years } & $-0.390 * * *$ & $-0.266^{* * *}$ & $-0.390 * * *$ & $-0.393 * * *$ \\
\hline & {$[0.035]$} & {$[0.034]$} & {$[0.035]$} & {$[0.035]$} \\
\hline \multirow[t]{2}{*}{$\%$ Female $25-54$} & $-0.059 * *$ & -0.033 & $-0.058 * *$ & $-0.059 * *$ \\
\hline & {$[0.026]$} & {$[0.025]$} & {$[0.027]$} & {$[0.027]$} \\
\hline \multirow[t]{2}{*}{$\%$ Female $>55$} & $-0.288 * * *$ & $-0.216^{* * *}$ & $-0.287 * * *$ & $-0.288 * * *$ \\
\hline & {$[0.077]$} & {$[0.076]$} & {$[0.077]$} & {$[0.079]$} \\
\hline \multirow[t]{2}{*}{ County Population 10,000s } & 0.000 & 0.000 & 0.000 & 0.000 \\
\hline & {$[0.000]$} & {$[0.000]$} & {$[0.000]$} & {$[0.000]$} \\
\hline \multirow[t]{2}{*}{ County Per Capita Income 1,000 s } & $0.006 * * *$ & $0.004 * * *$ & $0.006^{* * *}$ & $0.005 * * *$ \\
\hline & {$[0.001]$} & {$[0.001]$} & {$[0.001]$} & {$[0.001]$} \\
\hline \multirow[t]{2}{*}{ County per capita Medicaid discharges } & $-0.001^{*}$ & -0.001 & -0.001 & -0.001 \\
\hline & {$[0.001]$} & {$[0.001]$} & {$[0.001]$} & {$[0.001]$} \\
\hline Teaching Hospitals & $0.008 * *$ & $0.008 * *$ & $0.008 * *$ & $0.008 *$ \\
\hline & {$[0.004]$} & {$[0.003]$} & {$[0.004]$} & {$[0.004]$} \\
\hline CMS wage index & -0.001 & $-0.001 *$ & -0.001 & -0.001 \\
\hline & {$[0.000]$} & {$[0.000]$} & {$[0.001]$} & {$[0.001]$} \\
\hline Constant & $0.567 * * *$ & $0.666^{* * *}$ & $0.567 * * *$ & $0.560 * * *$ \\
\hline & {$[0.047]$} & {$[0.046]$} & [0.047] & [0.047] \\
\hline Observations & 4549 & 4549 & 4549 & 4399 \\
\hline R-squared & 0.29 & 0.35 & 0.29 & 0.29 \\
\hline
\end{tabular}

Robust standard errors in brackets

$*$ significant at $10 \%$; * significant at 5\%; *** significant at $1 \%$

all models include state and industry fixed effects 
Table 12: Effect of Choice on Proportion of covered Employees Enrolled in Family Coverage

\begin{tabular}{|c|c|c|c|c|}
\hline & \multicolumn{2}{|c|}{ OLS } & \multicolumn{2}{|c|}{ IV } \\
\hline & & & \multirow{2}{*}{$\begin{array}{c}\text { Full Sample } \\
\text { Model } 3\end{array}$} & \multirow{2}{*}{$\begin{array}{l}\text { HMO Available } \\
\text { in } 1996 \\
\text { Model } 4 \\
\end{array}$} \\
\hline & Model 1 & Model 2 & & \\
\hline \multirow[t]{2}{*}{ Offers Choice } & $0.027 * * *$ & $0.023 * * *$ & $-0.201 *$ & $-0.189 *$ \\
\hline & {$[0.008]$} & {$[0.008]$} & {$[0.103]$} & {$[0.102]$} \\
\hline \multirow[t]{2}{*}{$\%$ Wage $<\$ 10,000$} & & $-0.001 * * *$ & & \\
\hline & & {$[0.000]$} & & \\
\hline \multirow[t]{2}{*}{$\%$ Wage $\$ 10-14,000$} & & $-0.001 * * *$ & & \\
\hline & & {$[0.000]$} & & \\
\hline \multirow[t]{2}{*}{$\%$ Wage $\$ 14-20,000$} & & $-0.001 * * *$ & & \\
\hline & & {$[0.000]$} & & \\
\hline \multirow[t]{2}{*}{ 51-100 employees } & -0.002 & -0.001 & 0.016 & 0.015 \\
\hline & {$[0.009]$} & {$[0.009]$} & {$[0.013]$} & {$[0.013]$} \\
\hline \multirow[t]{2}{*}{ 101-250 employees } & $0.018^{*}$ & $0.020 * *$ & $0.057 * * *$ & $0.055 * * *$ \\
\hline & {$[0.010]$} & {$[0.010]$} & {$[0.021]$} & {$[0.020]$} \\
\hline \multirow[t]{2}{*}{ 250+ employees } & $0.046^{* * *}$ & $0.042 * * *$ & $0.123 * * *$ & $0.121 * * *$ \\
\hline & {$[0.011]$} & {$[0.011]$} & {$[0.037]$} & {$[0.037]$} \\
\hline \multirow[t]{2}{*}{ Part of a larger firm } & $0.051 * * *$ & $0.050 * * *$ & $0.079 * * *$ & $0.083 * * *$ \\
\hline & {$[0.008]$} & {$[0.008]$} & {$[0.015]$} & {$[0.015]$} \\
\hline \multirow[t]{2}{*}{ For Profit } & $0.023 *$ & $0.021 *$ & 0.015 & 0.012 \\
\hline & {$[0.012]$} & {$[0.012]$} & {$[0.014]$} & {$[0.014]$} \\
\hline \multirow[t]{2}{*}{ Health Expenditure Variation } & 0.054 & 0.046 & $0.095^{*}$ & $0.094 *$ \\
\hline & {$[0.048]$} & {$[0.048]$} & {$[0.055]$} & {$[0.055]$} \\
\hline \multirow[t]{2}{*}{$\%$ Male $<25$ years } & $-0.102 * * *$ & $-0.078 * *$ & $-0.107 * * *$ & $-0.107 * * *$ \\
\hline & {$[0.032]$} & {$[0.032]$} & {$[0.033]$} & {$[0.033]$} \\
\hline \multirow[t]{2}{*}{$\%$ Male $>55$} & 0.088 & 0.091 & $0.129^{*}$ & $0.117 *$ \\
\hline & {$[0.061]$} & {$[0.058]$} & {$[0.068]$} & {$[0.067]$} \\
\hline \multirow[t]{2}{*}{$\%$ Female $<25$ years } & $-0.128 * * *$ & $-0.087 * * *$ & $-0.126 * * *$ & $-0.141 * * *$ \\
\hline & {$[0.032]$} & {$[0.032]$} & {$[0.035]$} & {$[0.034]$} \\
\hline \multirow[t]{2}{*}{$\%$ Female $25-54$} & $-0.094 * * *$ & $-0.081 * * *$ & $-0.078 * * *$ & $-0.072 * * *$ \\
\hline & {$[0.023]$} & {$[0.023]$} & {$[0.027]$} & {$[0.027]$} \\
\hline \multirow[t]{2}{*}{$\%$ Female $>55$} & $-0.199 * * *$ & $-0.156 * *$ & $-0.188 * *$ & $-0.165 * *$ \\
\hline & {$[0.069]$} & {$[0.068]$} & {$[0.074]$} & {$[0.076]$} \\
\hline \multirow[t]{2}{*}{ County Population 10,000s } & 0 & 0 & 0 & 0 \\
\hline & {$[0.000]$} & {$[0.000]$} & {$[0.000]$} & {$[0.000]$} \\
\hline \multirow[t]{2}{*}{ County Per Capita Income $1,000 \mathrm{~s}$} & $-0.002 * *$ & $-0.003 * * *$ & -0.002 & $-0.002 *$ \\
\hline & {$[0.001]$} & {$[0.001]$} & {$[0.001]$} & {$[0.001]$} \\
\hline \multirow[t]{2}{*}{ County per capita Medicaid discharges } & $0.002 * * *$ & $0.002 * * *$ & 0.001 & 0.001 \\
\hline & {$[0.001]$} & {$[0.001]$} & {$[0.001]$} & {$[0.001]$} \\
\hline \multirow[t]{2}{*}{ Teaching Hospitals } & $-0.006^{*}$ & $-0.005 *$ & -0.002 & -0.001 \\
\hline & {$[0.003]$} & {$[0.003]$} & {$[0.004]$} & {$[0.004]$} \\
\hline CMS wage index & 0 & 0 & 0 & 0 \\
\hline & {$[0.000]$} & {$[0.000]$} & {$[0.001]$} & {$[0.001]$} \\
\hline Constant & $0.465 * * *$ & $0.519 * * *$ & $0.466 * * *$ & $0.453 * * *$ \\
\hline & {$[0.043]$} & {$[0.043]$} & {$[0.046]$} & {$[0.046]$} \\
\hline Observations & 4549 & 4549 & 4549 & 4399 \\
\hline R-squared & 0.1 & 0.12 & & \\
\hline
\end{tabular}

Robust standard errors in brackets

* significant at $10 \%$;* significant at $5 \%$; ** significant at $1 \%$

all models include state and industry fixed effects 
Table 13: Effect of Choice on Probability of Offering a Full Contribution Plan

\begin{tabular}{|c|c|c|c|c|c|c|}
\hline & \multicolumn{3}{|c|}{ Single Coverage } & \multicolumn{3}{|c|}{ Family Coverage } \\
\hline & \multirow[t]{2}{*}{ OLS } & \multicolumn{2}{|c|}{ IV } & \multirow[t]{2}{*}{ OLS } & \multicolumn{2}{|c|}{ IV } \\
\hline & & Full Sample & $\begin{array}{l}\text { HMO Available } \\
\text { in } 1996\end{array}$ & & Full Sample & $\begin{array}{c}\text { HMO Available } \\
\text { in } 1996\end{array}$ \\
\hline & Model 1 & Model 2 & Model 3 & Model 4 & Model 5 & Model 6 \\
\hline \multirow[t]{2}{*}{ Offers Choice } & $0.082 * * *$ & 0.257 & 0.212 & $0.045 * * *$ & -0.058 & -0.023 \\
\hline & {$[0.016]$} & {$[0.188]$} & {$[0.186]$} & {$[0.012]$} & [0.133] & {$[0.132]$} \\
\hline \multirow[t]{2}{*}{ 51-100 employees } & $-0.043 * *$ & $-0.057 * *$ & $-0.050 * *$ & -0.02 & -0.011 & -0.015 \\
\hline & {$[0.018]$} & {$[0.024]$} & {$[0.024]$} & {$[0.013]$} & {$[0.017]$} & {$[0.017]$} \\
\hline \multirow[t]{2}{*}{ 101-250 employees } & $-0.081 * * *$ & $-0.111 * * *$ & $-0.104 * * *$ & $-0.030 * *$ & -0.012 & -0.02 \\
\hline & {$[0.020]$} & {$[0.038]$} & [0.038] & {$[0.014]$} & {$[0.027]$} & {$[0.027]$} \\
\hline \multirow[t]{2}{*}{$250+$ employees } & $-0.100 * * *$ & $-0.159 * *$ & $-0.144 * *$ & 0 & 0.035 & 0.021 \\
\hline & {$[0.025]$} & {$[0.069]$} & {$[0.068]$} & {$[0.019]$} & {$[0.049]$} & {$[0.049]$} \\
\hline \multirow[t]{2}{*}{ Part of a larger firm } & $-0.052 * * *$ & $-0.074 * * *$ & $-0.072 * *$ & -0.01 & 0.003 & -0.005 \\
\hline & {$[0.015]$} & {$[0.028]$} & {$[0.028]$} & {$[0.011]$} & {$[0.019]$} & {$[0.020]$} \\
\hline \multirow[t]{2}{*}{ For Profit } & $-0.111 * * *$ & $-0.104 * * *$ & $-0.106 * * *$ & $-0.070 * * *$ & $-0.074 * * *$ & $-0.074 * * *$ \\
\hline & {$[0.025]$} & {$[0.026]$} & {$[0.027]$} & {$[0.020]$} & {$[0.020]$} & {$[0.021]$} \\
\hline \multirow[t]{2}{*}{ Health Expenditure Variation } & 0.084 & 0.052 & 0.074 & -0.028 & -0.009 & -0.011 \\
\hline & {$[0.087]$} & {$[0.096]$} & {$[0.096]$} & {$[0.069]$} & {$[0.074]$} & {$[0.075]$} \\
\hline \multirow[t]{2}{*}{$\%$ Male $<25$ years } & -0.008 & -0.004 & 0.003 & -0.053 & -0.056 & -0.055 \\
\hline & {$[0.057]$} & {$[0.057]$} & {$[0.058]$} & {$[0.043]$} & {$[0.043]$} & {$[0.043]$} \\
\hline \multirow[t]{2}{*}{$\%$ Male $>55$} & 0.125 & 0.093 & 0.116 & 0.022 & 0.04 & 0.033 \\
\hline & {$[0.126]$} & {$[0.134]$} & [0.133] & [0.103] & {$[0.105]$} & {$[0.106]$} \\
\hline \multirow[t]{2}{*}{$\%$ Female $<25$ years } & $-0.127 * *$ & $-0.129 * *$ & $-0.136^{* *}$ & -0.055 & -0.054 & -0.064 \\
\hline & {$[0.059]$} & {$[0.060]$} & {$[0.060]$} & {$[0.044]$} & {$[0.044]$} & {$[0.045]$} \\
\hline \multirow[t]{2}{*}{$\%$ Female $25-54$} & -0.003 & -0.016 & -0.011 & $-0.074 * *$ & $-0.067^{*}$ & $-0.069^{*}$ \\
\hline & {$[0.046]$} & {$[0.048]$} & {$[0.049]$} & {$[0.035]$} & {$[0.037]$} & {$[0.038]$} \\
\hline \multirow[t]{2}{*}{$\%$ Female $>55$} & $-0.278 * *$ & $-0.286^{* *} *$ & $-0.311 * *$ & 0.039 & 0.044 & 0.042 \\
\hline & {$[0.131]$} & {$[0.134]$} & {$[0.135]$} & [0.099] & {$[0.101]$} & {$[0.102]$} \\
\hline \multirow[t]{2}{*}{ County Population $10,000 \mathrm{~s}$} & 0 & 0 & 0 & $0.001 * * *$ & $0.001 * * *$ & $0.001 * * *$ \\
\hline & {$[0.000]$} & {$[0.000]$} & {$[0.000]$} & {$[0.000]$} & {$[0.000]$} & {$[0.000]$} \\
\hline \multirow[t]{2}{*}{ County Per Capita Income 1,000 s } & 0.001 & 0.001 & 0.001 & -0.002 & -0.002 & -0.002 \\
\hline & {$[0.002]$} & {$[0.002]$} & {$[0.002]$} & {$[0.002]$} & {$[0.002]$} & {$[0.002]$} \\
\hline \multirow[t]{2}{*}{ County per capita Medicaid discharges } & 0.001 & 0.001 & 0.001 & $0.003 * * *$ & $0.003^{* *}$ & $0.003 * * *$ \\
\hline & {$[0.001]$} & {$[0.001]$} & {$[0.001]$} & {$[0.001]$} & {$[0.001]$} & {$[0.001]$} \\
\hline \multirow[t]{2}{*}{ Teaching Hospitals } & -0.001 & -0.004 & -0.004 & $-0.010 * *$ & -0.008 & $-0.009^{*}$ \\
\hline & {$[0.006]$} & {$[0.007]$} & {$[0.007]$} & {$[0.005]$} & {$[0.005]$} & {$[0.005]$} \\
\hline \multirow[t]{2}{*}{ CMS wage index } & 0.000 & 0.000 & 0.000 & 0.000 & 0.000 & 0.000 \\
\hline & {$[0.001]$} & {$[0.001]$} & {$[0.001]$} & {$[0.001]$} & {$[0.001]$} & {$[0.001]$} \\
\hline \multirow[t]{2}{*}{ Constant } & $0.487 * * *$ & $0.486 * * *$ & $0.490 * * *$ & $0.121 *$ & $0.121 *$ & $0.132 * *$ \\
\hline & {$[0.087]$} & {$[0.088]$} & [0.089] & {$[0.066]$} & {$[0.066]$} & {$[0.067]$} \\
\hline Observations & 4549 & 4549 & 4399 & 4549 & 4549 & 4399 \\
\hline R-squared & 0.06 & 0.03 & 0.04 & 0.04 & 0.03 & 0.04 \\
\hline
\end{tabular}

Robust standard errors in brackets

$*$ significant at $10 \% ; * *$ significant at $5 \% ; * * *$ significant at $1 \%$

all models include state and industry fixed effects 
Appendix Table 1: Descriptive Statistics for Variables used in Premium Standardization Model

\begin{tabular}{|c|c|c|}
\hline $\mathrm{N}=19,031$ & & \\
\hline Variable & Mean & Std. Dev \\
\hline Plan Premium for Single Coverage & 148.94 & 67.23 \\
\hline HMO plan & 0.20 & 0.40 \\
\hline PPO plan & 0.31 & 0.46 \\
\hline POS plan & 0.05 & 0.22 \\
\hline Employer offers Choice & 0.43 & 0.49 \\
\hline HMO*Choice & 0.13 & 0.34 \\
\hline PPO*Choice & 0.12 & 0.32 \\
\hline POS*Choice & 0.02 & 0.15 \\
\hline Deductible & 252.89 & 359.29 \\
\hline Coinsurance Rate & 16.06 & 10.20 \\
\hline Employee Stop Loss & 0.77 & 0.42 \\
\hline Plan Self-Insured & 0.24 & 0.43 \\
\hline Prenatal Coverage & 0.93 & 0.26 \\
\hline Maternity Coverage & 0.93 & 0.25 \\
\hline Prescription Drug Coverage & 0.89 & 0.32 \\
\hline Mental Health Coverage & 0.93 & 0.26 \\
\hline Alcohol Coverage & 0.90 & 0.30 \\
\hline Dental Coverage & 0.28 & 0.45 \\
\hline$\%$ Male $<25$ years & 0.10 & 0.14 \\
\hline$\%$ Male $25-54$ & 0.39 & 0.26 \\
\hline$\%$ Male $>=55$ & 0.06 & 0.10 \\
\hline$\%$ Female $<25$ years & 0.09 & 0.14 \\
\hline$\%$ Female $25-54$ & 0.33 & 0.25 \\
\hline$\%$ Female $>=55$ & 0.04 & 0.09 \\
\hline$\%$ Wage $<\$ 10,000$ & 10.82 & 21.39 \\
\hline$\%$ Wage $\$ 10-14,000$ & 20.33 & 24.15 \\
\hline$\%$ Wage $\$ 14-20,000$ & 24.13 & 22.82 \\
\hline$\%$ Wage $>\$ 20,000$ & 44.75 & 33.70 \\
\hline 1-10 employees & 0.36 & 0.48 \\
\hline 11-25 employees & 0.26 & 0.44 \\
\hline 26-50 employees & 0.13 & 0.34 \\
\hline 51-100 employees & 0.09 & 0.29 \\
\hline 101-250 employees & 0.09 & 0.28 \\
\hline $250+$ employees & 0.07 & 0.26 \\
\hline Part of a larger firm & 0.49 & 0.50 \\
\hline Agriculture/Forestry \& Fisheries & 0.02 & 0.14 \\
\hline Construction & 0.05 & 0.21 \\
\hline Mining and Manufacturing & 0.14 & 0.34 \\
\hline Transportation/Communications/Oth & 0.05 & 0.21 \\
\hline Wholesale Trade & 0.09 & 0.29 \\
\hline Retail Trade & 0.20 & 0.40 \\
\hline Finance/Insurance/Real Estate & 0.20 & 0.40 \\
\hline Professional Services & 0.21 & 0.41 \\
\hline Other Services & 0.04 & 0.19 \\
\hline Colorado & 0.09 & 0.29 \\
\hline Florida & 0.10 & 0.30 \\
\hline Minnesota & 0.09 & 0.28 \\
\hline New Mexico & 0.10 & 0.30 \\
\hline New York & 0.13 & 0.34 \\
\hline North Dakota & 0.08 & 0.27 \\
\hline Oklahoma & 0.09 & 0.29 \\
\hline Oregon & 0.11 & 0.31 \\
\hline Vermont & 0.10 & 0.29 \\
\hline Washington & 0.11 & 0.32 \\
\hline
\end{tabular}


Appendix Table 2: Model of Plan Premiums - Single Coverage

\begin{tabular}{|c|c|c|}
\hline Variable & Coeff & Std Error \\
\hline HMO plan & $-24.862 * * *$ & {$[2.217]$} \\
\hline PPO plan & $-8.552 * * *$ & {$[1.465]$} \\
\hline POS plan & $-13.776 * * *$ & [2.956] \\
\hline Employer offers Choice & -1.329 & [1.563] \\
\hline HMO*Choice & $8.362 * * *$ & {$[2.734]$} \\
\hline PPO*Choice & $4.657^{* *}$ & [2.309] \\
\hline POS*Choice & -1.469 & [4.447] \\
\hline Deductible & $-0.014 * * *$ & {$[0.003]$} \\
\hline Deductible $^{\wedge} 2$ & $0.000 * * *$ & {$[0.000]$} \\
\hline Coinsurance Rate & $-0.185 * * *$ & {$[0.047]$} \\
\hline Employee Stop Loss & $3.377 * *$ & [1.409] \\
\hline Plan Self-Insured & 0.67 & {$[1.278]$} \\
\hline Prenatal Coverage & $6.976 * *$ & [2.892] \\
\hline Maternity Coverage & 0.136 & [3.072] \\
\hline Prescription Drug Coverage & $6.249 * * *$ & [1.592] \\
\hline Mental Health Coverage & 2.73 & [2.119] \\
\hline Alcohol Coverage & $3.277^{*}$ & {$[1.810]$} \\
\hline Dental Coverage & $9.166^{* * *}$ & [1.083] \\
\hline$\%$ Male $<25$ years & $-18.515 * * *$ & [3.985] \\
\hline$\%$ Male $>=55$ & $47.901 * * *$ & [4.963] \\
\hline$\%$ Female $<25$ years & -0.319 & {$[3.824]$} \\
\hline$\%$ Female $25-54$ & $13.399 * * *$ & {$[2.450]$} \\
\hline$\%$ Female $>=55$ & $44.731 * * *$ & {$[5.742]$} \\
\hline$\%$ Wage $<\$ 10,000$ & -0.022 & {$[0.026]$} \\
\hline$\%$ Wage $\$ 10-14,000$ & $-0.096 * * *$ & {$[0.021]$} \\
\hline$\%$ Wage $\$ 14-20,000$ & $-0.051 * *$ & {$[0.022]$} \\
\hline 1-10 employees & $9.957 * * *$ & [2.131] \\
\hline 11-25 employees & $6.542 * * *$ & [2.119] \\
\hline 26-50 employees & 1.917 & [2.263] \\
\hline 51-100 employees & -1.402 & [2.373] \\
\hline 101-250 employees & -0.75 & [2.389] \\
\hline Part of a larger firm & $-2.161 * *$ & [1.083] \\
\hline Constant & $126.369 * * *$ & {$[5.440]$} \\
\hline Observations & 19031 & \\
\hline R-squared & 0.07 & \\
\hline
\end{tabular}

Standard errors in brackets

* significant at $10 \% ; * *$ significant at $5 \% ; * * *$ significant at $1 \%$ all models include state and industry fixed effects 